\title{
Research Paper \\ Agricultural Commercialization in Rural Farming Systems and Causal Interpretation of its Determinants Using Structural Equation Modeling and Path Analysis
}

\author{
*Abbas Amini ${ }^{1}$ \\ 1. Associate Professor, Department of Geography and Rural Planning, Faculty of Geographical Sciences and Planning, University of Isfahan, Isfahan, Iran.
}

cittation: Amini, A. (2016). Agricultural Commercialization in Rural Farming Systems and Causal Interpretation of its Determinants Using Structural Equation Modeling and Path Analysis. Journal of Rural Research. 7(3), 546-563. http://dx.doi.org/10.21859/jjr-07039

: http://dx.doi.org/10.21859/jjr-07039

Received: 3 Apr. 2016

Accepted: 6 Jul. 2016

Keywords:

Strawberry commercialization, Rural smallholders, Causal interpretation, Structural modeling

\section{A B STRACT}

Commercial agriculture means production in large scale, specialized, and market-oriented cropping. The present study aims to identify the commercialization components of strawberry cultivation in Marivan township and to evaluate its determinants causally. A stratified random sample comprising of 191 stakeholders were interviewed to collect data. The dependent variables of strawberry cropping commercialization includes the area under cultivation, crop specialization, crop intensification, under cultivation area addition, crop yield and sale proportion. A set of economic, social, technical, and institutional factors operationalized and measured as the independent variables. Measuring of dependent scale was modeled using confirmatory factor analysis (CFA) and the path analysis approach was used to interpret its causal relationships with independent variables. Farms average area under cultivation, literacy and acquaintance of the family head, satisfaction with job and future hopefulness, informal vocational training, the degree of modern irrigation usage and level of wage labor utilization were the final constructive variables set of the study's causal-structural model. First three variables are external- while the remaining are internal-structural model variables. Based on the total direct and indirect effects, farms average area under cultivation, satisfaction with job and future hopefulness and degree of modern irrigation usage had the most influence on commercialization of strawberry cultivation. Contrarily, the level of wage labor utilization, acquaintance, and literacy of the family head had minor influences on the commercialization of the strawberry.

\section{Extended Abstract}

\section{Introduction}

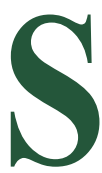

ocieties' food security and moving toward development, entails the transition of the primary sector from traditional subsistence farming systems to advanced commercial ones. Commercial agriculture generally means production in large scale beyond the basic needs, with specialized, market-ori- ented and marketed cropping. The inevitable policy of commercializing agriculture to achieve the simultaneous aims of promoting the economic development nationally as well as improving the poor rural livelihood and rural economic development regionally entails noticing and planning for all types of farming systems, i.e. from small scale to big corporations. Focusing on various more beneficiary crops via practicing the rural and peasantry farms, on different regional climates corresponding to the properties and physiological requirements of these crops is one of the important schemes to achieve rural economic growth programs.

* Corresponding Author:

Abbas Amini, PhD

Address: Department of Geography and Rural Planning, Faculty of Geographical Sciences and Planning, University of Isfahan, Isfahan, Iran. Tel: +98 (913) 1290940

E-mail: a.amini@geo.ui.ac.ir 
Some of the instances are the specialized cultivation of crops such as saffron, cotton, rape, peanut, summer crops market gardening, vegetables, oilseeds cultivation, pistachio gardening, flowering, strawberry cultivation, etc. in some of Iran's rural areas. This approach is investigated by several studies as the agricultural diversification, aiming the replacement of traditional strategic and low productive crops with the more technical and beneficiary ones, accompanied by its various impacts on social and economical structures of the rural areas. The present study aims to identify and introduce the commercialization components of strawberry cultivation as the main agricultural product of Marivan Township and evaluate its determinants causally.

\section{Methodology}

A stratified random sample comprising of 191 strawberry cultivators were interviewed to compile the needed data, based on a self-designed and validated questionnaire. Dependent variable of strawberry cropping commercialization has operationalized considering the area under cultivation, cropping specialization, cropping intensification, under cultivation area addition, crop yield, sale proportion and Packing. A set of economic, social, technical, and institutional factors as the independent variables were operationalized and measured differently with appropriate questions. The variables were the age, literacy and acquaintance of the family head, family size, farms average area under cultivation, degree of modern irrigation usage, level of wage labor utilization (non-familial structure of the farming system), informal vocational trainings, satisfaction and hopes with the job and its future, product warehouse and maintenance equipment, and transportation infrastructures (on all weather road). Evaluation of commercialized strawberry cultivation, as a dependent scale, was modeled and validated using the statistical procedure of confirmatory factor analysis (CFA). Biased observed variables were eliminated from the final scale. Amos Graphics was performed to standardize the path coefficients.

\section{Results}

The regression analysis weighs, crop intensity and crop specialty as more determinant in predicting commercialization followed by the other components such as crop yield, marketed production and cultivation expansion by the crop's income. The statistical path analysis approach was used to interpret the causal relationships of commercialization with independent variables as well of their interrelation causalities. Path analysis diagram is a drawing based on theoretical considerations regarding the causal order of antecedent and consequent variables. One of the complementary distinguishing procedures to do this is multi-stage perform- ing multiple regressions, which is leading to the conceptual framework and analytical model of the study. Farms average area under cultivation, literacy and acquaintance of the family head, satisfaction with job and future hopefulness, informal vocational trainings, degree of modern irrigation usage and level of wage labor utilization have been the final constructive variables set of the study's causal-structural model. The first three variables are external and the remaining are internal structural model variables.

\section{Discussions}

The final causal-structural model is combination of several multivariate path models. The external and internal variables have influenced the strawberry cropping commercialization via six direct as well of twenty seven indirect paths because of their inter-casualty relations. Based on the total direct and indirect effects, farms average area under cultivation, satisfaction with job and future hopefulness and degree of modern irrigation usage had the most influence on commercialization of strawberry cultivation. The level of wage labor utilization, acquaintance and literacy of the family head had minimal effect on commercialization of strawberry.

\section{Conclusion}

Increasing modernity in recent century has made strong evolution in the economy of developing countries from primary sector business to more industrial level. A statistically significant decline in agriculture's contribution to macroeconomic indices of developing countries is seen. Nevertheless, the social and economic viability of many rural communities in these countries depends highly on farming activities and entails its development. Provision and promotion of food security, creation and durability of job and income opportunities and development of farming as well as non-farming activities are some aspects to be considered for the redemption of property in the peripheral rural communities. The difficulty faced by such poor and isolated rural communities as well as their small and traditional farms is their impotency to challenge with current contingences, which in no way are consistent with them.

On one hand, sub-optimal utilization of their small and sparse lands and water resources does not give them competitive ability for meeting their economical needs. On the other hand, it is, for many reasons, impossible the consolidation of their lands and mechanization to have a share from economy of scale. Thus, the attention and emphasis must be paid to other factors and approaches than to modernize and commercialize the small rural holders and actualize their 
potentials to cope with their needs successfully. Specialized cropping with regards to different regional and geographical properties is one of the major approaches to optimize the productive potencies of disperse small scale farmers. Some of the non-compromising requisites are as strengthening of production systems by input (seeds, fertilizers, machines, equipment etc.) and output (products) flows, development of conducive social structures, development of research, education and advisory institutions, development and enhancement of infrastructures such as all weather roads, power, communication and irrigations systems, transportation, warehousing and marketing facilities and processing industries. 


\title{
تجارىشدن كشاورزى در بهرهبردارىهاى روستايى و واكاوى عوامل مؤثر بر آن با رويكرد مدلسازى ساختارى و تحليل مسير ترون
}

\author{
"عباس امينى' \\ 1- دانشيار، كروه جغرافياو برئامهريزى روستايى، دانشكده علوم جغرافياييى وبرنامهريزى، دانشعاه اصفهان، اصفهان، ايران.
}

Citation: Amini, A. (2016). Agricultural Commercialization in Rural Farming Systems and Causal Interpretation of its Determinants Using Structural Equation Modeling and Path Analysis. Journal of Rural Research. 7(3), 546-563. http://dx.doi.org/10.21859/jjr-07039

doi : http://dx.doi.org/10.21859/jjr-07039

افزونبر اين، رفع نيازهاى متنوع و جديدى كه در دنياى بري

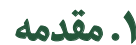

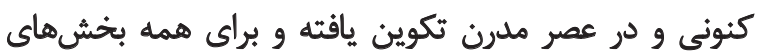

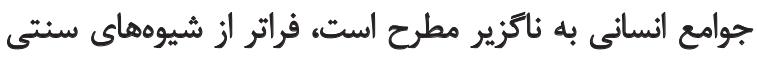

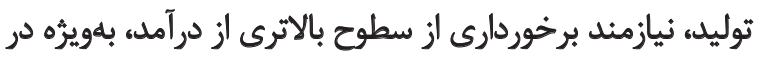

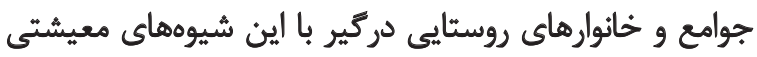

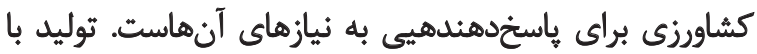

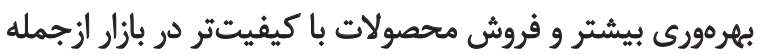
كزينههايى است كه در اين راستا مطرح مي مئرود.

در اين شيوه كشت كه به كشاورزى و كشت تجارى مرسوم

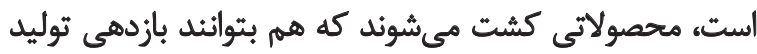

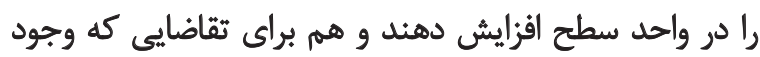
دارد، فروش خوبى در بازار داشته باشند. بهرهبردارى دهاى تقائ تجارى

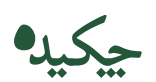

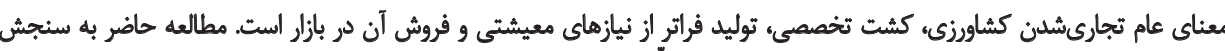

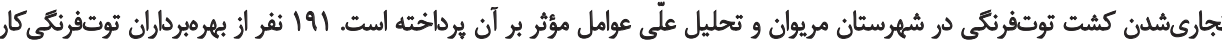

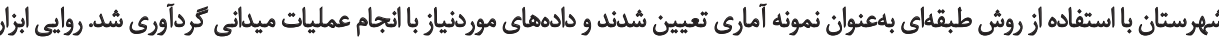

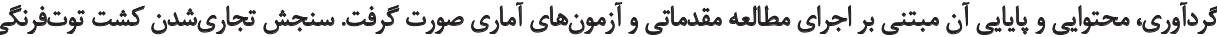

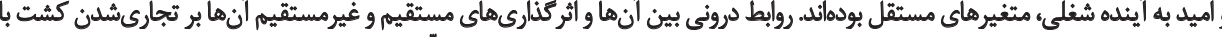

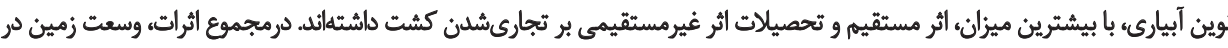

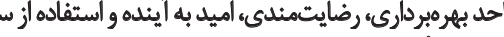

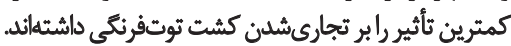

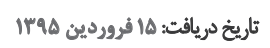

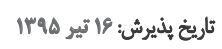

كليدوازوهها:

تجارىشدن كشاورزى،

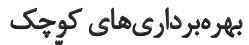
روستايي، تثبيين عليّ،

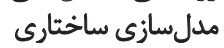

تنوع كشت، الكوى غالب در بيشتر نظامهاي سنتى زراعى در مزارع

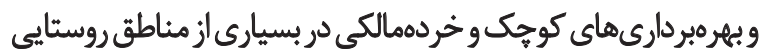

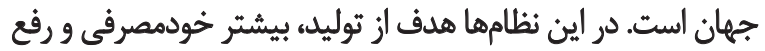

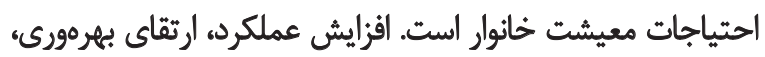

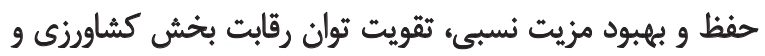

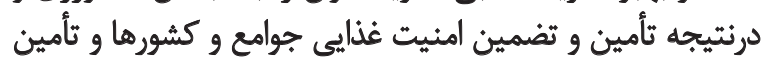

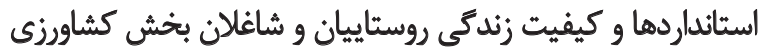

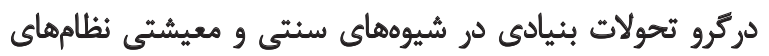

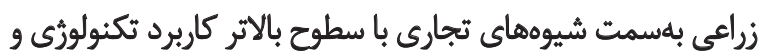

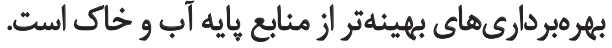


تجارىشلن كشت توتفرنكى بهعنوان محصول اصلى در

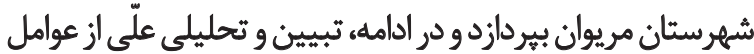

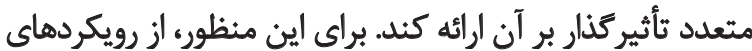

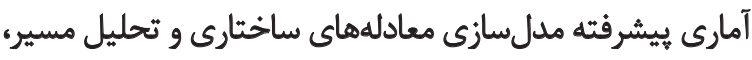

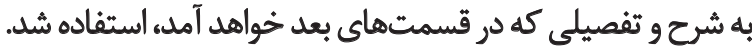

در ايران، كشت توتفرئكى از حدود اواخر دوره قاجار

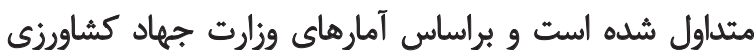

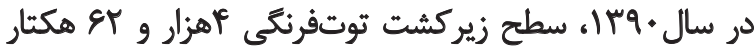

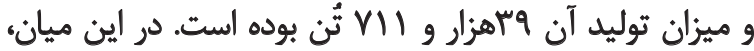

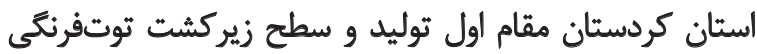

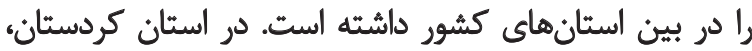

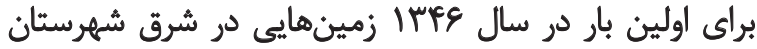

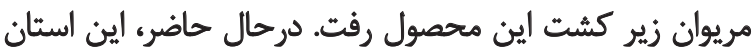

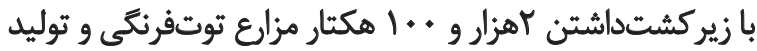

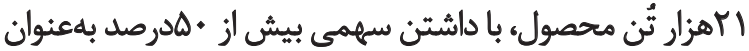

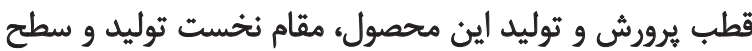

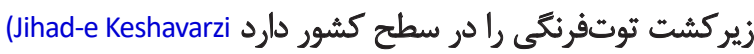
Organization of Kurdistan Province, 2012).

\section{ז. مرورى بر ادبيات موضوع}

\section{تجارى شدن كشاورزى و الكَوهاي ثخصصى كشت}

نظامهاى كشاورزى تجارى روى دو كروه از محصولات

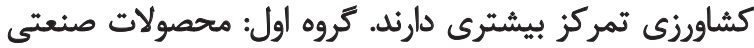

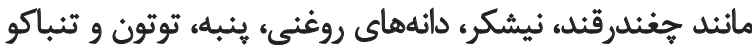

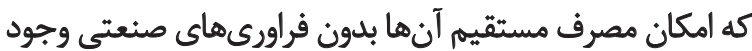

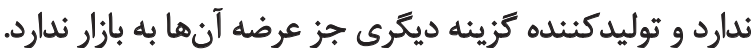

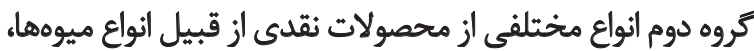

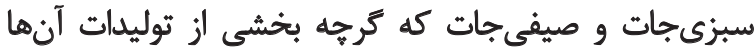
قابليت خودمصرفى در واحدهاي توليدي

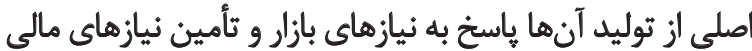
توليدكنيدكان آنهاست.

ويزوكىها و نيازمندى تهاى متفاوت انواع مختلف محصولات

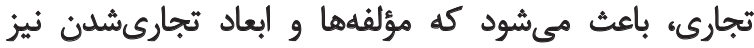

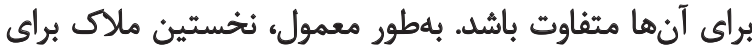

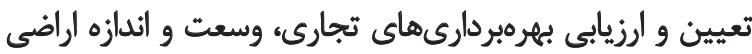

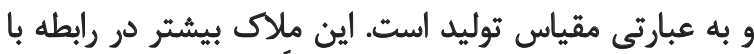

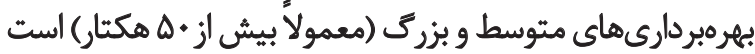

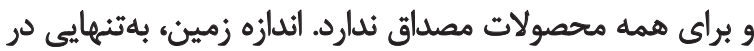

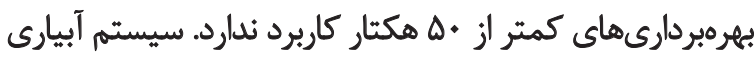

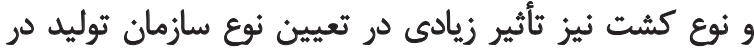

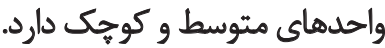
به كَفته اشرف (T1941)، ممكن است واحدهاى كوحكى كه
واحدهاي بازر كاني هستند كه مبناى كارشان كسب سود از راه

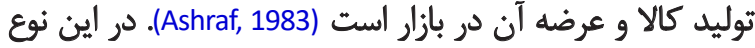

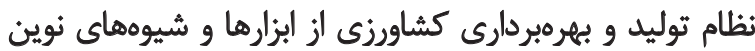

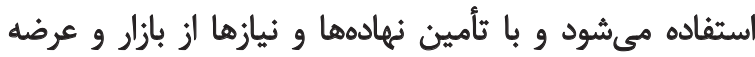
محصولات به بازار، ارتباطى دوجانبه با آن دارد (Najafi, 1997). ازجمله واقعيتهاى مسلم و بازدارنده در نظامهاى سنتى إنى إنى

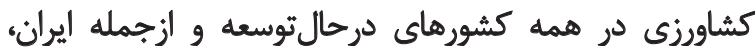

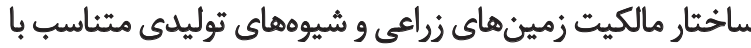

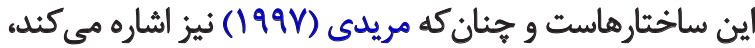

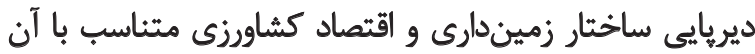
ازجمله مشكلات سياست كذارى در بخش كشاورزى ايران است. در بستر جنين ساختارهايى، امكان تغييرات اساسى و كلان

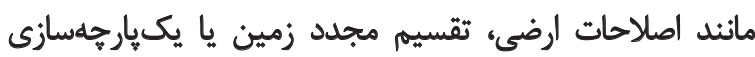

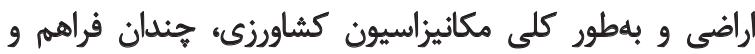

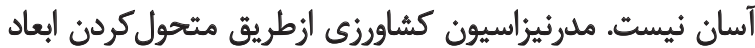

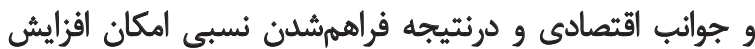

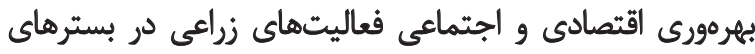

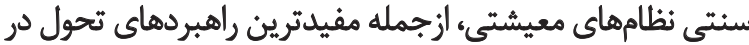

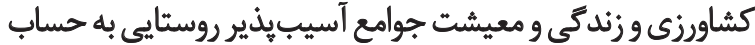

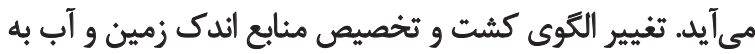

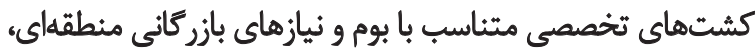

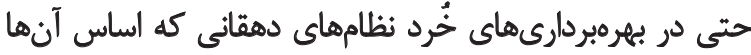

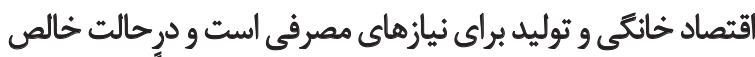

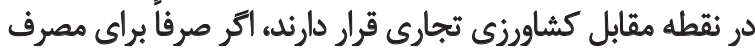

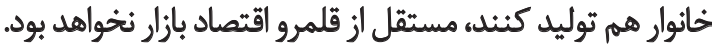
بنابراين، اكرجه زمين يكى إز مههمترين عوامل بإيهاي توليد در

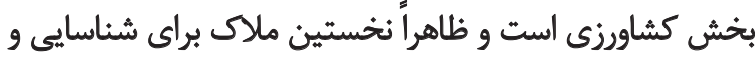

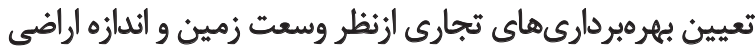

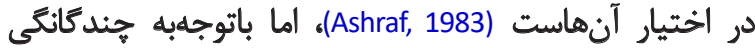

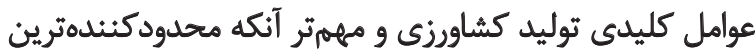

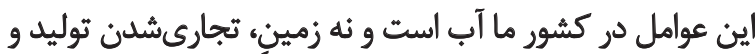

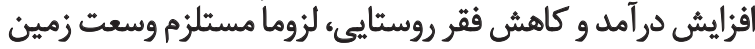

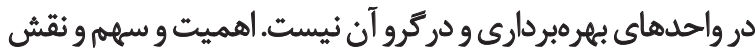

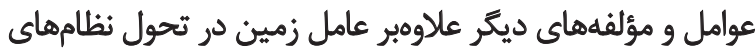

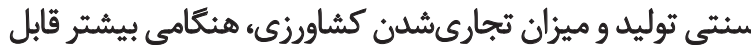

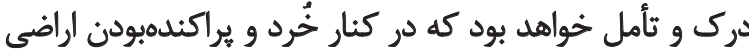

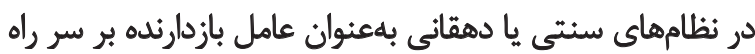

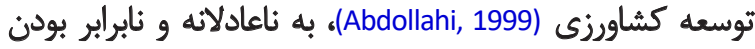
توزيع زمين در نظام ارضى كشاورزى ايران در همه ادوار مختلف نائف (Azimi, 1983) نيز نظر داشته باشيه.

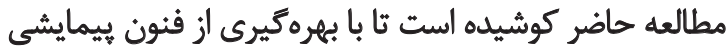
و مبتنى بر دادههاي ملموس و واقعى، ابتدا به سنجش ميزان إنون بيماني 
و نابرابر زمين را به الكوى متعادل ترى از توزيع درآمد در ميان بهرهبردارى ها و بهرهبرداران كشاورزى تبديل كندي

بنابراين، در كشاورزى ايران كه زمين عامل محدودكنيده نيست

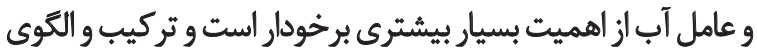

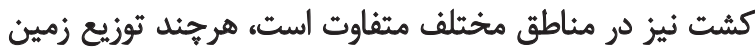

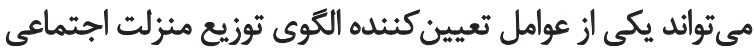

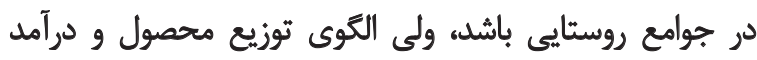

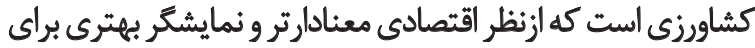
تصوير فقر و غناى روستايى بلهمار مى آيد (Azimi, 1983). تمركز و تأكيد بر راهبردهاى برشمردهشيده، همجينان امكان

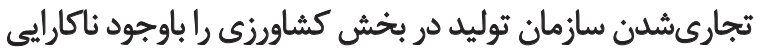

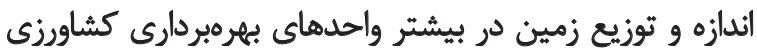

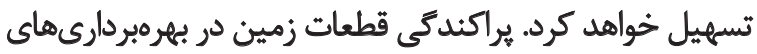

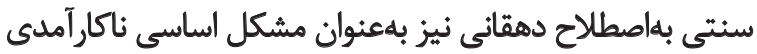

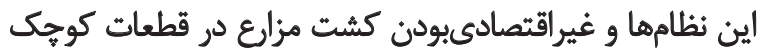

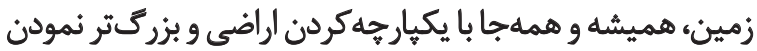

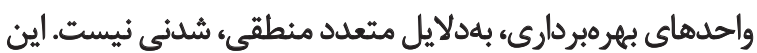

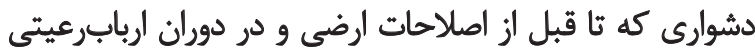

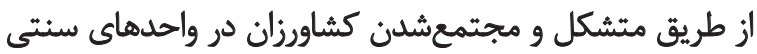

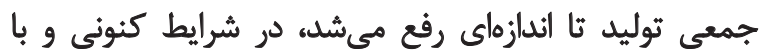

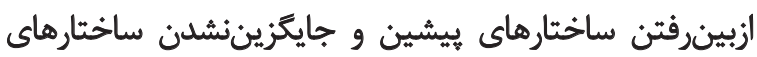

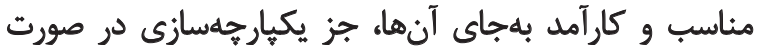

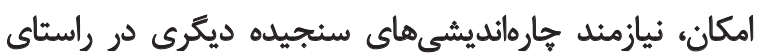
افزايش توليد و بهرهورى و كاستن از فقر روستائيى است. تمركز بر عوامل ديكر توليد كشاورزى، مائند آب؛ نيروى كاري

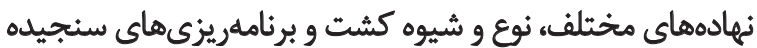

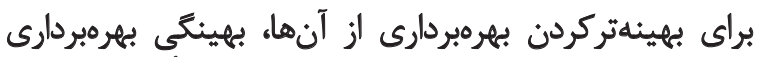

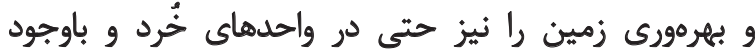

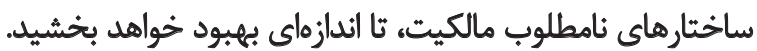

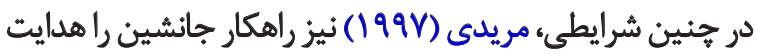

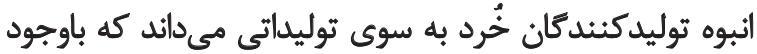

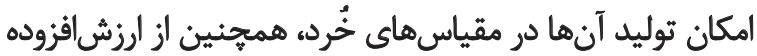

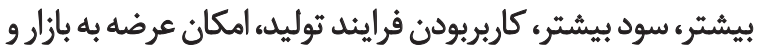

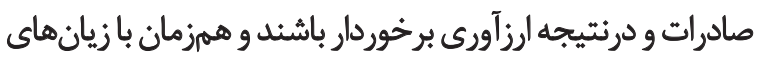

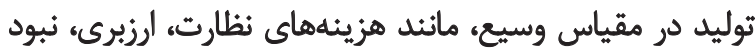

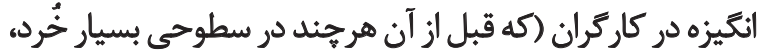
مالك زمين بودهاند) و.... همراه نباشندان آنرجن.

تجارىشدن و تجارىسازى مفاهيمى هستئد كه ارتباط

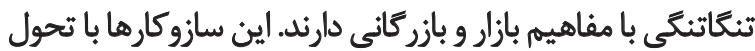

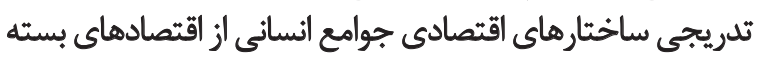

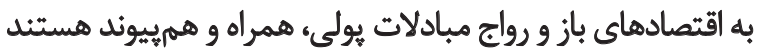

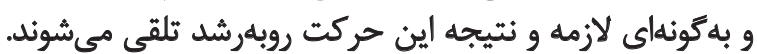

با يكى دو هكثار زمين به توليد محصولاتى همجيون سبزى جات

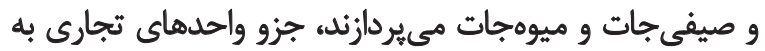

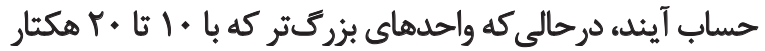

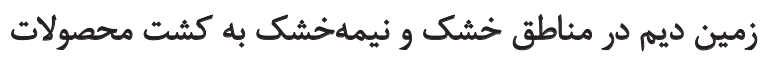

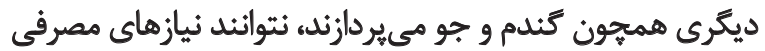

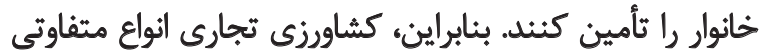

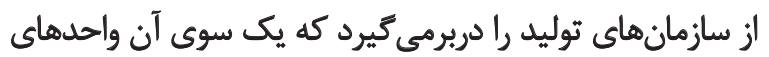

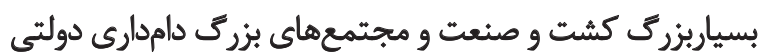

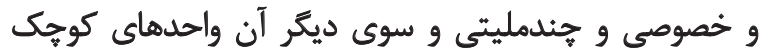

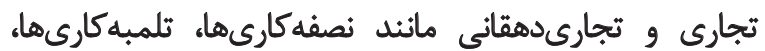

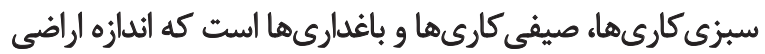

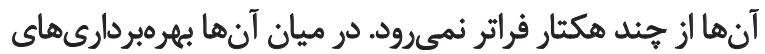

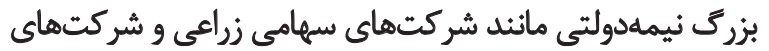

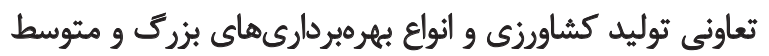
خصوصى قرار مى گيرند (Ashraf, 1983).

تجارىشدن كشاورزى، عامل زمين و محدوديتهاى آن جنان كه اشاره شد، دو مشكل عمده در رابطه با عامل زمين و ورئ

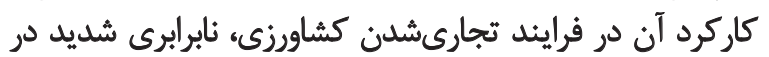

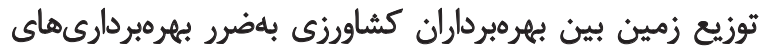

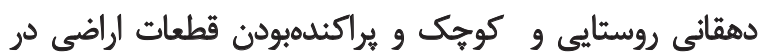

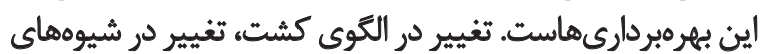

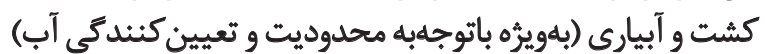

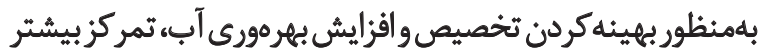

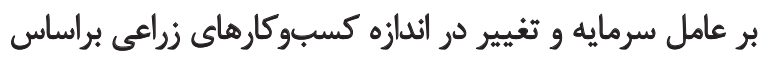

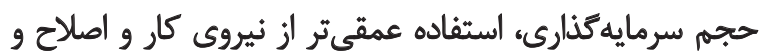

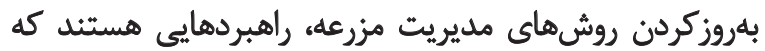

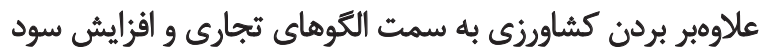

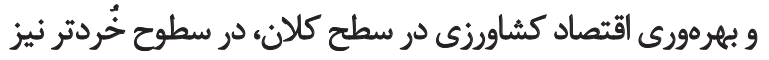

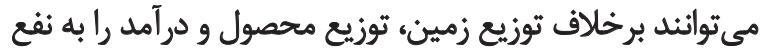

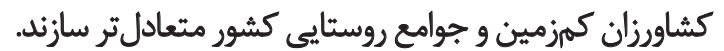
بررسى اقتصادى و آمارى در رابطه با الكوهاى توزيع زمين و ورائ

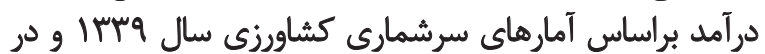

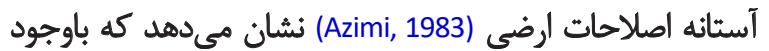

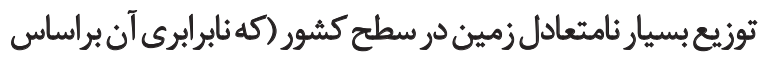

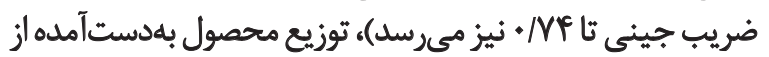

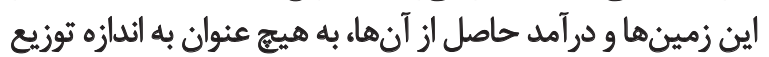

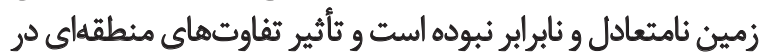

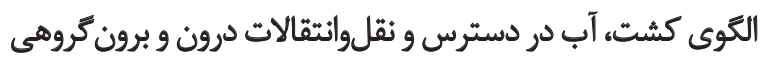

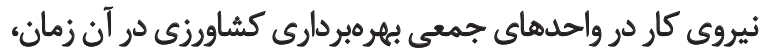

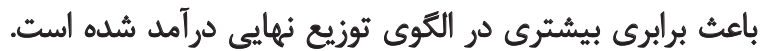

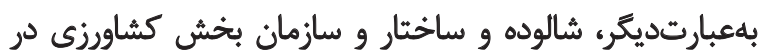

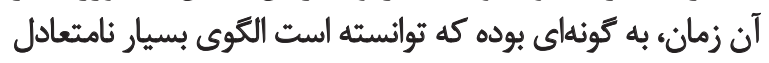




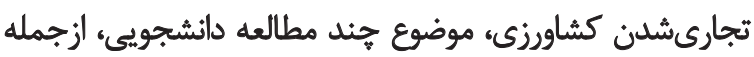

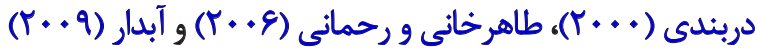

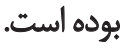

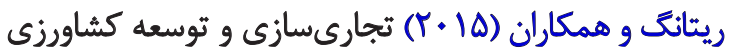

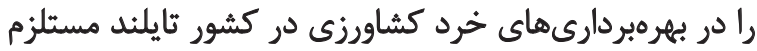

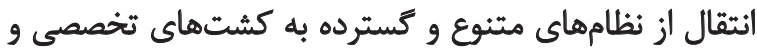

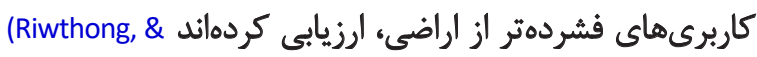
Schreinemachers, Grovermann \& Berger, 2015).

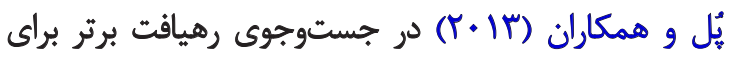

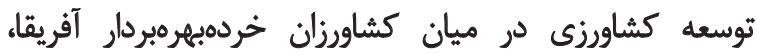

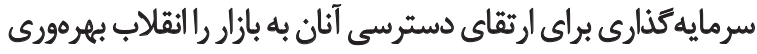

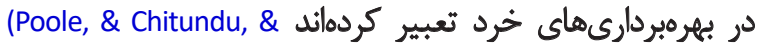

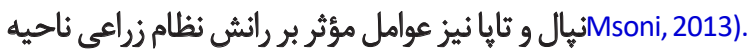

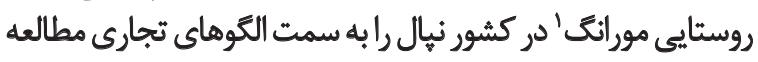

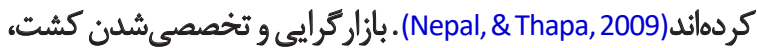

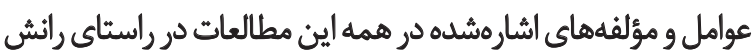
نظامهاى زراعى به سمت توسعه و يايدارى بودهاند. ". روش شُناسى تحقيق معرفى مختصر منطقه مطالعهشده شهرستان مريوان در ها آ كيلومترى غرب استان كردستان، بين هf

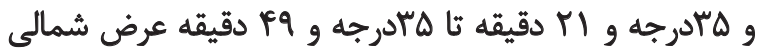

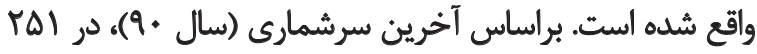

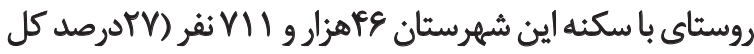

1. Morang

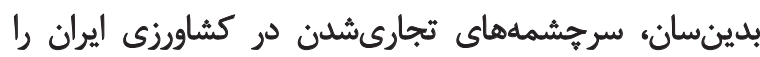

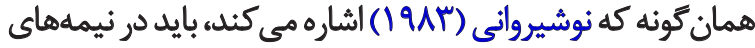

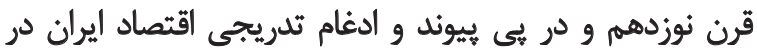

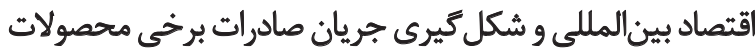

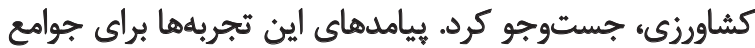

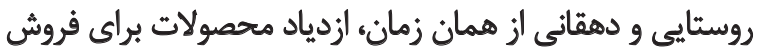

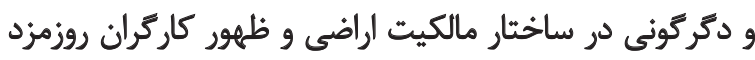

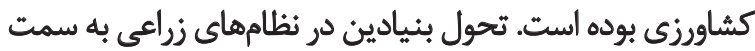

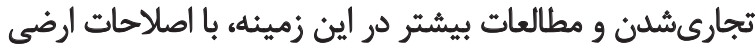

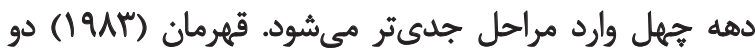

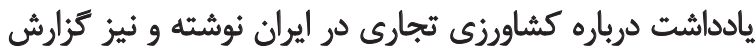

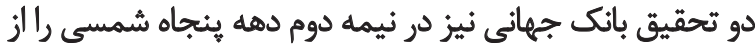

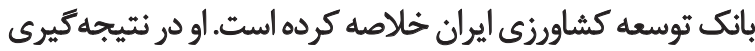

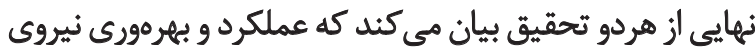

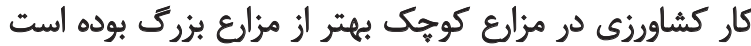

.(Ghahreman, 1983)

اين نتيجه كه با نتيجه يُزوهش تطبيقى عبداللهى (1999)

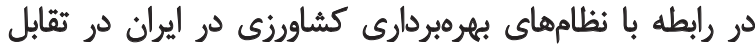

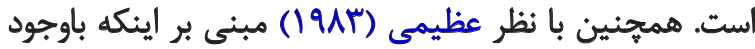

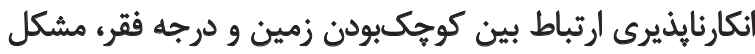

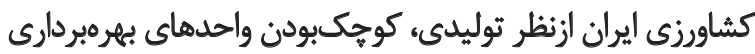

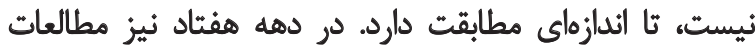

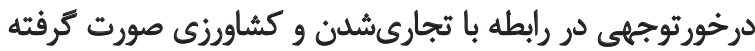

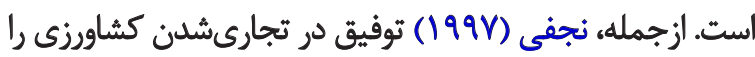

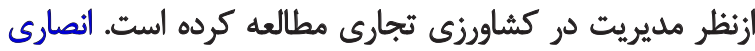
(199V) با تلقى تجارى (19)

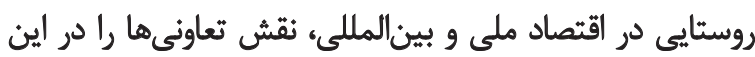

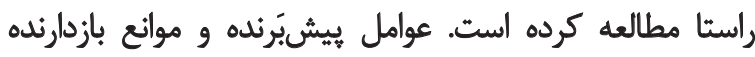

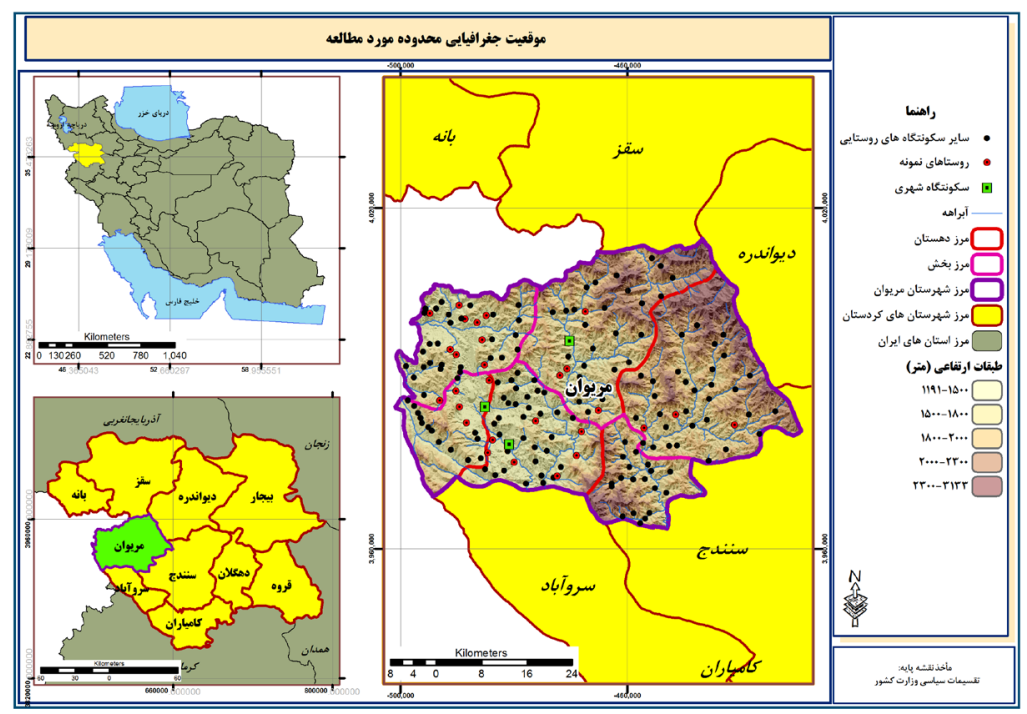


رويكردهاى آمارى براى تحليل دادهها، روشهائ بيشرفئه

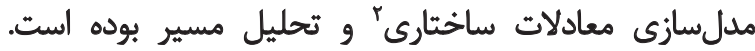

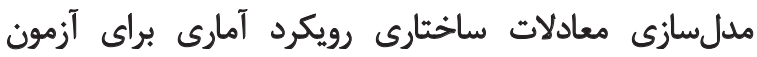

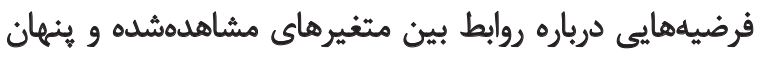
و تركيبى از مدل هاى اندازهذيرى و مدل هائ ساختارى است.

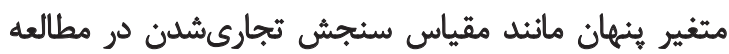

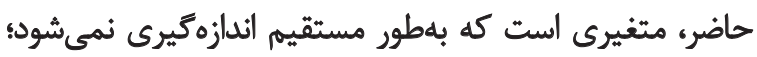

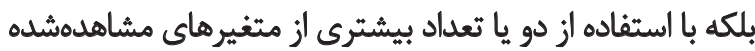

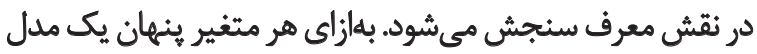

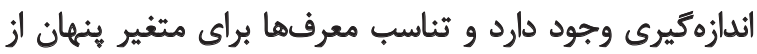

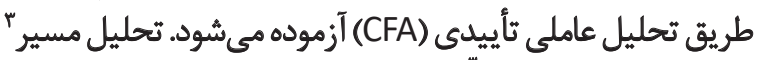

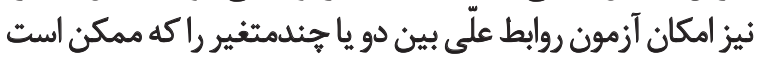

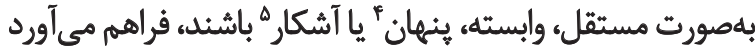

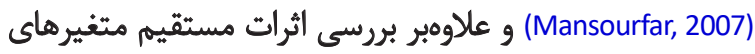

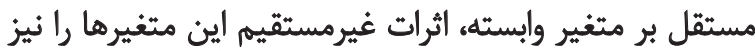

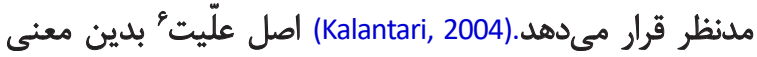

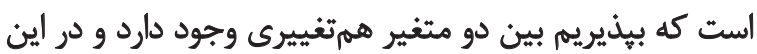

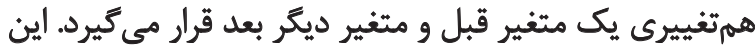

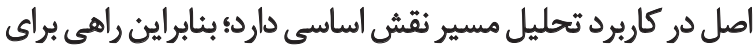

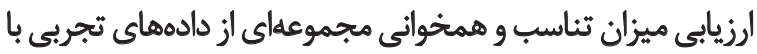
مدل نظرى تحقيق است.(Mansourfar, 2007)

ع. عافتهانها

\section{توصيف آمارى ثمونه بروسى شده و ويؤَّى هاي توليدى زوراعى آثان}

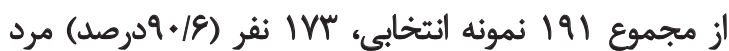

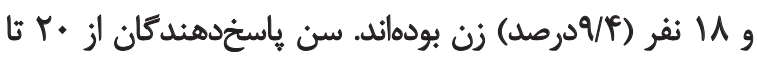

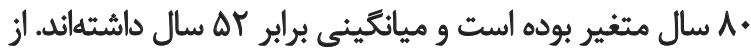

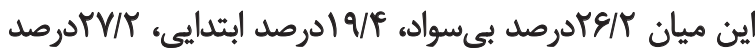

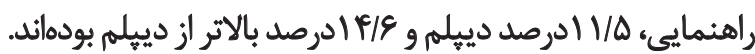

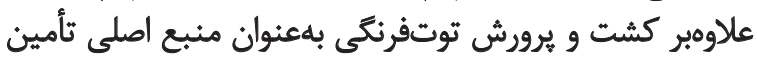

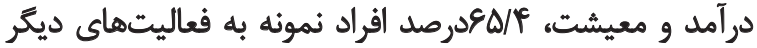

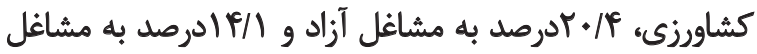

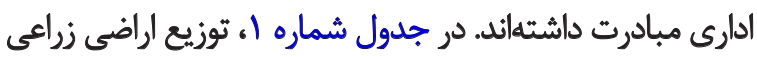

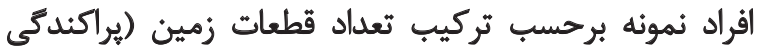
اراضى) در سطوح مختلف زيركشت بيان شده است.

جنانكه ملاحظه مي شوده، شكل غالب در بهرهبردارىهاى

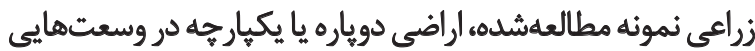

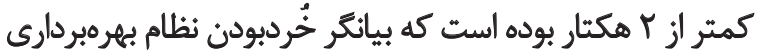

2. Structural equation modeling

3. Path analysis

4. Latent

5. Observed

6. Causality
جمعيت) زندكى مي كنئد. تصوير شماره ا، موقعيت جغرافيايى

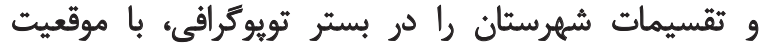
سكونتكاههاى شهرى و روستايى آن نشان مى دهند.

روش مطالعه (جامعله، ثمونه، دادهها، ابزار ترّدآورى و متثيرهاى تحقيث)

مطالعه حاضر، يروهشى توصيفى تحليلى و ويمايشى و مقطعى

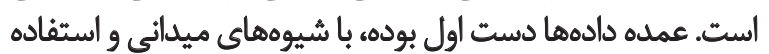

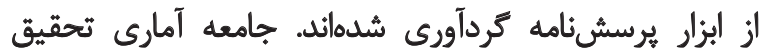

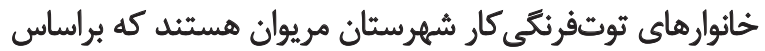

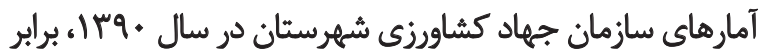

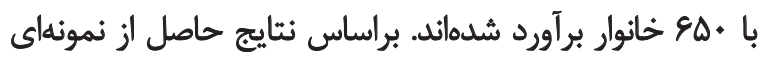

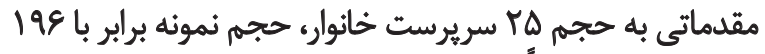

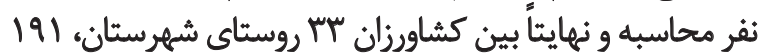

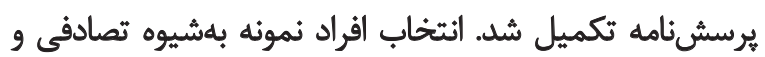
توزيع آنها با انتساب مثناسب صورت كرفته است

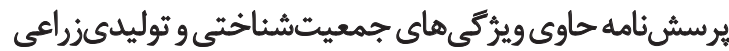

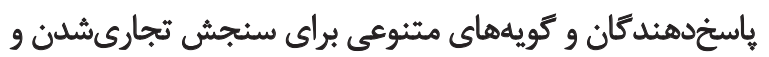

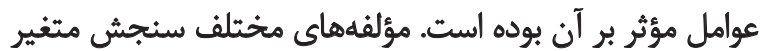

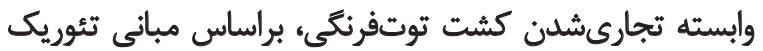

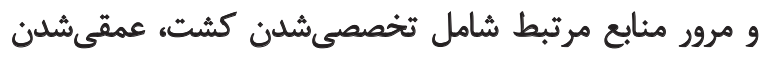

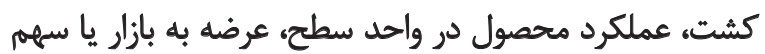

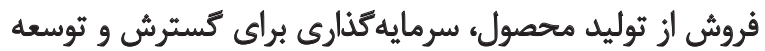

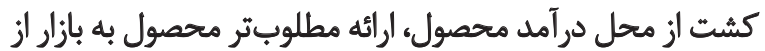
طريق بستهبندى و افزايش باز الريسندى محصول بوائ مطوداند. عملياتى كردن و سنجش متغير هاى مستقل شامل متغيرهاى

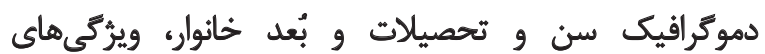

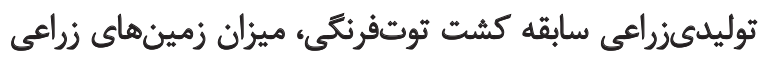

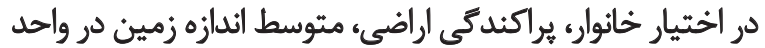

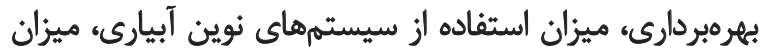

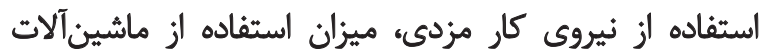

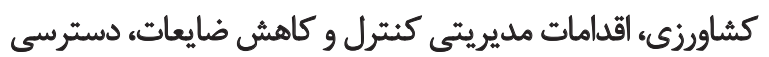

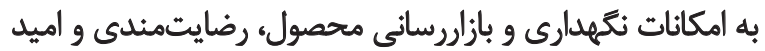

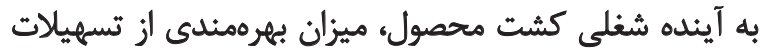

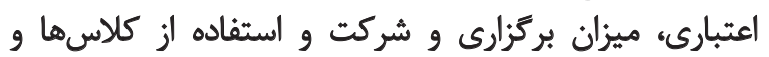

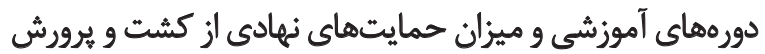

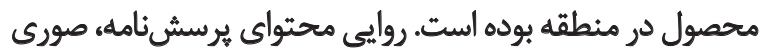

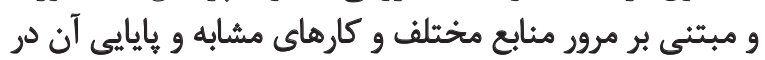

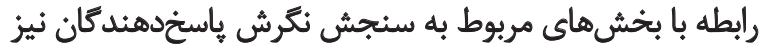

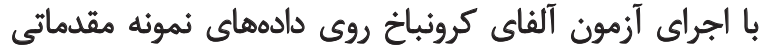

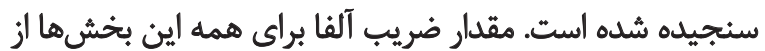

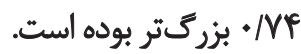


جدول ا. تركيب نمونه برحسب توزيع اراضى زراعى در قطعات و سطوح مختلف زير كشت.

\begin{tabular}{|c|c|c|c|c|c|}
\hline \multicolumn{5}{|c|}{ يراكندكى اراضى (تعداد قطعات) } & \multirow{2}{*}{ سطح الراضي زير كشت } \\
\hline مجموع & ع قطعه & بقطعه & Y Yقطعه & ( قطعه (يكيار جهـ) & \\
\hline$\Delta r$ & - & - & 10 & rv & كمثر از 1 هكثار \\
\hline$n^{e}$ & . & 1 & r & r. & 1/A تأ هكتار \\
\hline$\Delta f$ & 1 & 10 & r & $\Delta$ & 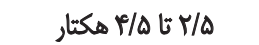 \\
\hline 11 & r & $\checkmark$ & r & . & بيش از هـ هكتار \\
\hline 191 & r & r & צ" & $r$ & مجموع \\
\hline
\end{tabular}

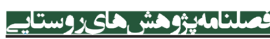

آموزش براى اين جامعه هدف را بهخوبى روشن مى مسازد. بلويثه

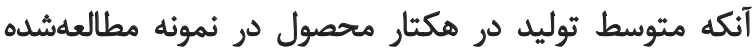

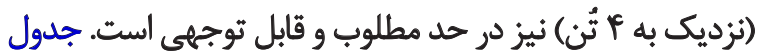

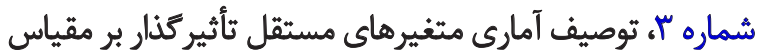

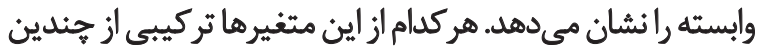

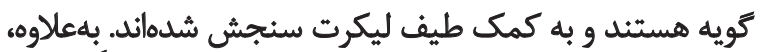

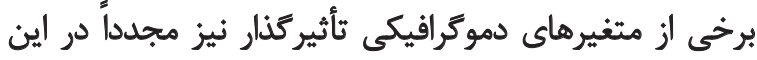
جدول ارائه و توصيف شدهاند.

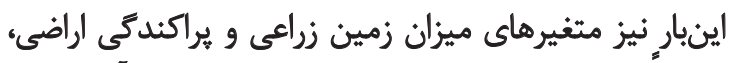

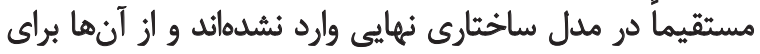

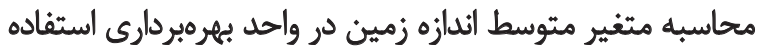

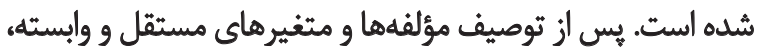

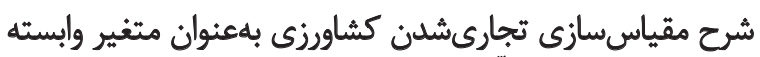

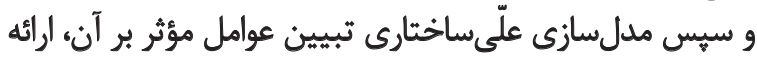

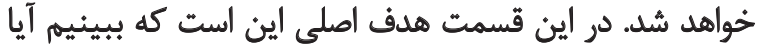

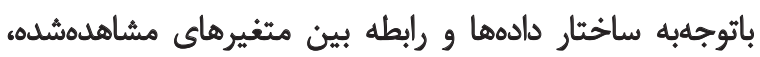

\section{زراعى منطقه است. \\ توصيف أمارى مثغير هاى تحقيث}

جدول شماره r توصيف آمارى مثغيرهاى اوليه براى

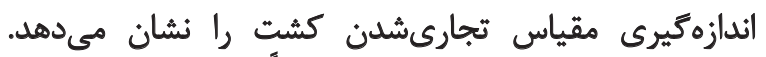

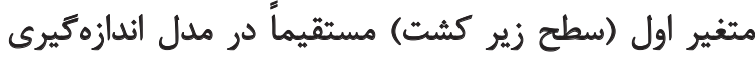

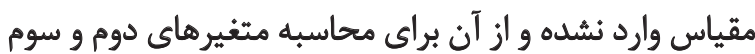
(تخصصى شدن و عملكرد محصول) استفاده شده است.

جنانكه ملاحظه مىشود، باوجود اينكه بلهطور متوسط

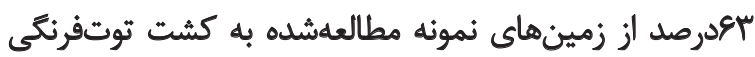

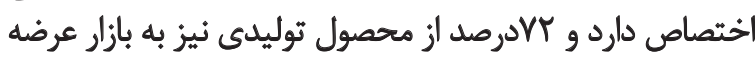

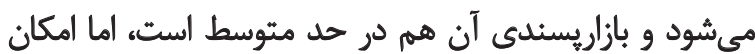

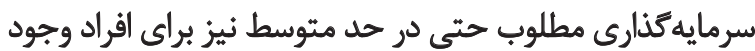

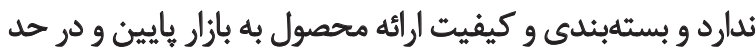

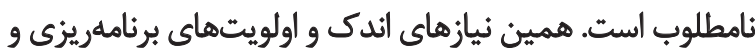

جدول r. معرفى و توصيف آمارى مؤلفههاى مقياس وابسته تجارىشدن كشت توتفرنكى.

\begin{tabular}{|c|c|c|c|c|}
\hline اتحرافمعيار & مياتكين & 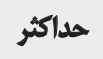 & حداقل & مؤلفهاى تجارى شُدن (متثيرهاى مشاهدهشده) \\
\hline.$/ v 9$ & $1 / \pi \Delta$ & $\Delta$ &.$/ \Delta$. & سطح زير كشت توتفرنكى (هكتار) \\
\hline$r \Delta / r$ & str & $1 .$. & 1. & تخصصى شلن كشت محصول (سهم محصول (درصد) از كل سطح زيركشت) \\
\hline M. & r/u & 1 &.$/ v a$ & عملكرد محصول توتفرنكى (تُن در هكتار) \\
\hline $10 / \Delta$ & $r$ & $1 .$. & ra & هيزان (درصد) فروش محصول توليدشده (توليد براى فروش يا عرضه محصول به بازار) \\
\hline $1 / M^{e}$ & q/Re & if & $\Delta$ & عمقى شلن كشت محصول (تعلاد جين يا دفعات برداشت محصول در سال زراعى) \\
\hline $1 / 91$ & r & r & . & بستلبنلى محصول توليدشهه (ليكرت: تركيب سل كويه) \\
\hline .49 & $r / q 1$ & r & V/aV & بازاريسنلى و استقبال و رضايت از كيفيت محصول عرضهشه به بازار (ليكرت: تركيب بنج كويه) \\
\hline.$/ \mathrm{s}$ & $r / \& V$ & r & 1 & ميزان بس|نداز ز محل درآهد محصول و سرمايه كنارى آن براى توسعه كشت (ليكرت: تركيب سه كويه) \\
\hline
\end{tabular}


جدول ب. تركيب و توصيف آمارى متغيرهاي مستثل تأثيركذار بر تجارىشدن كشت توتفرئكى.

\begin{tabular}{|c|c|c|c|c|c|}
\hline انتحرافمعيار & مياتكّين & 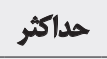 & حداقل & 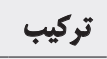 & متغير هاى مستقل \\
\hline \multicolumn{6}{|c|}{ ويوتى هاى فردى و زراعى سريرست خانوار } \\
\hline (يميانه سني) & & A. & 1 & - & سن (سال) \\
\hline 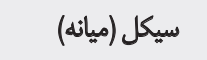 & & 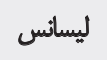 & 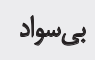 & - & تحصيلات (توزيع فراوائى مقاطع تحصيلى) \\
\hline$+/ 8 \Delta$ & T/MT & $f$ & 1 & - & بُعد خانوار (نفر) \\
\hline$r / \Lambda \cdot$ & g/g. & 10 & $r$ & - & سابقه كشت و يرورش توتفرنكى (سال) \\
\hline Tr/ & $\mathrm{M} / \mathrm{M}$ & $\Lambda$ &.$/ \Delta$ & - & ميزان زمين زراعى (مجموع سطع زيركشت: هكتار) \\
\hline.$N$ & INE & r & 1 & - & براكندى اراضى (تعداد قطعات زمين) \\
\hline$\cdot / \mathrm{M} 9$ & $1 / \%$ & 8 &.$/ \Delta$ & - & هتوسط اندازه زمين در واحل بهرهبردارى (هكتار) \\
\hline$r \cdot 18$ & $1 Y / 9$ & \&. & . & - & ميزان استفاده از سيستمهاى نوين آبيارى (درصد اراضى) \\
\hline rige & $\Delta+18$. & $1 .$. & $r \cdot$ & - & هيزان استثفاده از نيروى كار دستمزدى (درصد) \\
\hline -/AT & $r / \bullet 1$ & $\varphi$ & - & 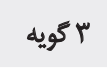 & استفاده از مانشين آلات كشاورزى (در مراحل مختلف كاشت و داشت و بردانشت محصول) \\
\hline.$/ 8 \Delta$ & T/Ma & $p$ & 1 & بويه & كنترل و كاهش ضايعات (ناشي از آقات و هنكام برداشت و حمل محصول) \\
\hline.$/ \Delta 9$ & T/RT & $H / \Delta$ & $V / \Delta$. & 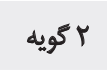 & دسترسى به امكائات نتكهارى و به بازار رسائلن محصول \\
\hline$+N$ & $m / t$ & $\Delta$ & r & 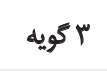 & رضايثمندى و اميد به آينذه شغلى \\
\hline.$/ 109$ & T/GT & $f / \Delta$ & $V / \Delta$ & r ب اكويه & ميزان بهرهمندى از تسهيلات اعتبارى \\
\hline$\cdot / 8$ & r/gr & $f$ & 1 & بويه & بركزازى و شركت و استفاده از كلاس ها و دورههاى أموزشى تخصصى و حرفهاى \\
\hline$\cdot / \Delta r$ & $r / A P$ & rier & $1 / m$ & ب اكويه & حمايتهاي نهادى و دولثئى \\
\hline
\end{tabular}

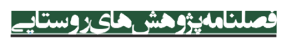

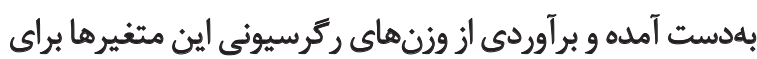

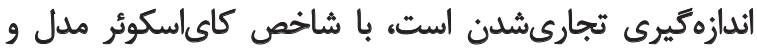
سطح معنادارى آن نشان مى دهد.

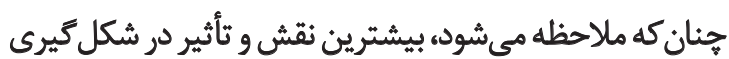

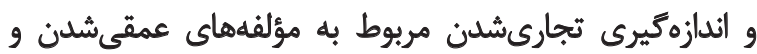

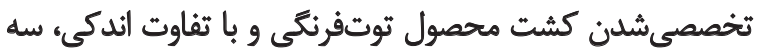

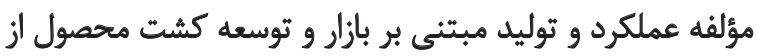

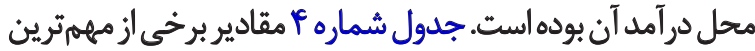

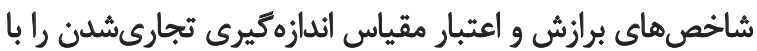

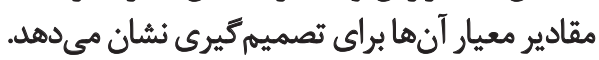

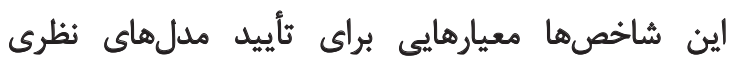

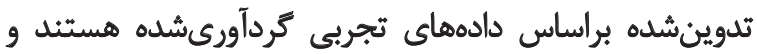

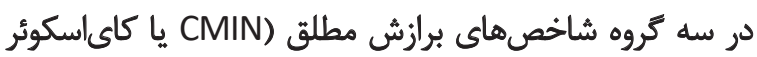

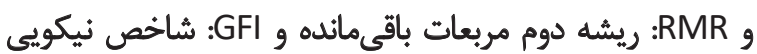

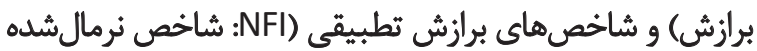

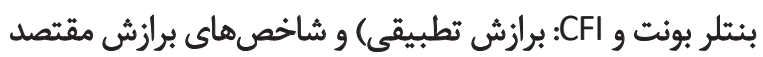

مى توان مدل معتبرى براى سنجش تجارىشدن و تبيين علّى

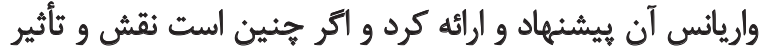

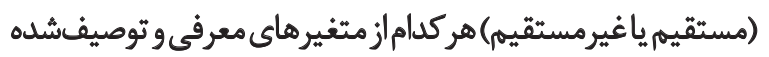

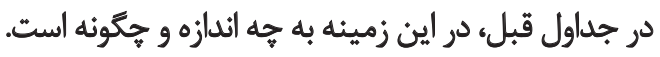

مقياس سازٔى تجارىشدن كشت با رويكرد مدل سازى معادلات

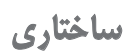

ساختن مقياس اندازهيرى تجارى ششدن كشت ثوتفرنكىى، با بارئ

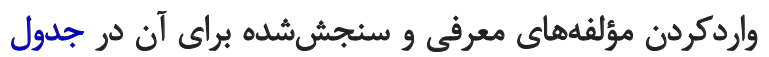

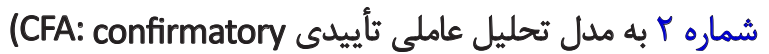

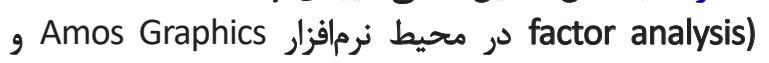

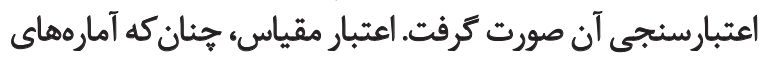

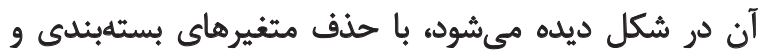

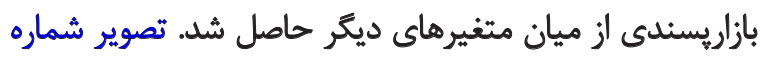

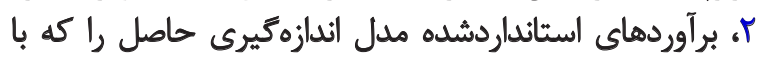

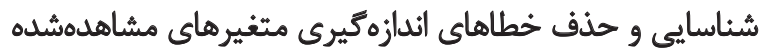




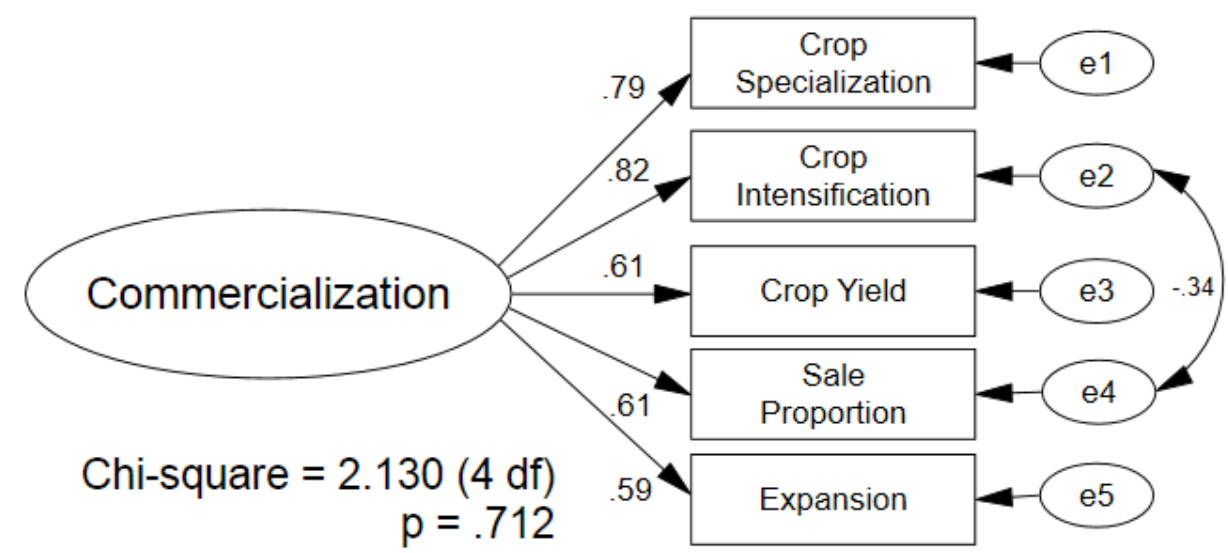

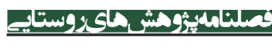

تصوير با. برآوردهاى استاندارد مدل تحليل عاملى تأييدى براى اندازهكيرى مقياس تجارى شدن كشاورزى.

و كوواريانس نمونهاى حاصل از متغيرهاي مشاهدهشده و ماتريس

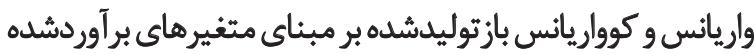

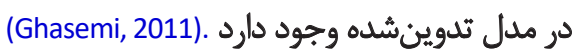

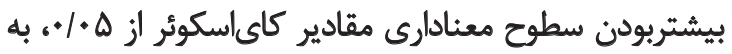

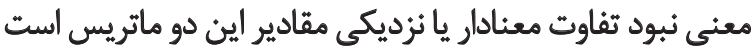

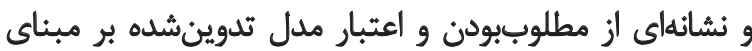

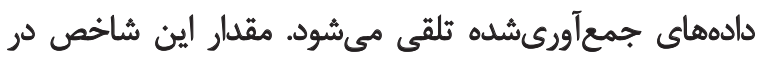

: نسبت صرفهجويى و RRATIO) ريشه ميانكين مربعات

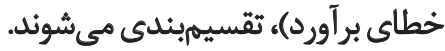
تمام هفت شاخص ذكرشده اعتبار و برازش بسيارخوب مدل

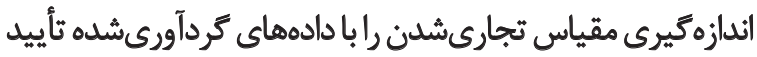

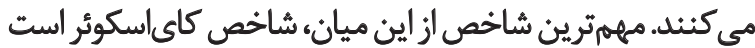

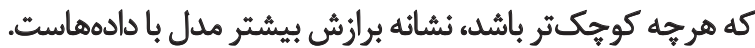

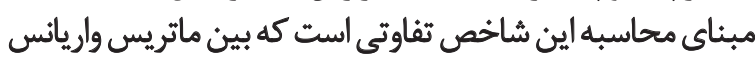

جدول F. شاخصهاى برازش مدل تحليل عاملى تأييدى براى اندازهيرى تجارىشدن كشاوزىى.

\begin{tabular}{|c|c|c|c|c|c|c|c|c|c|}
\hline \multicolumn{9}{|c|}{ شاخص هاى برازٔش } & \multirow{3}{*}{ مقياس تجارى تُشدن كثتى } \\
\hline RMSEA & PRATIO & CFI & NFI & GFI & RMR & Sig. & df & CMIN & \\
\hline$+1+4$ & $+/ \varepsilon$ & 1 &.$/ 994$ & $1 / 997$ & $+1+1 \mathrm{~V}$ & $+|V|$ & $\varepsilon$ & $r / I r$ & \\
\hline$<+1 \cdot \Delta$ & $\cdot-1$ & $>\cdot 19$ & $>. / 9$ & $>\cdot / 9$ & $\approx$ & $>.1 .0$ & - & - & هقادير هعيار يبيشنهادي" \\
\hline
\end{tabular}

جدول هـ برآوردهاى استاندارد مؤلفههاي مقياس تجارىشدن كشاورزى و سطح معنادارى آنها.

\begin{tabular}{|c|c|c|c|c|}
\hline سطح معنادارى & خطاى استاثيارد & نسبت بحرائى & 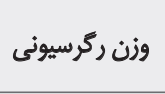 & 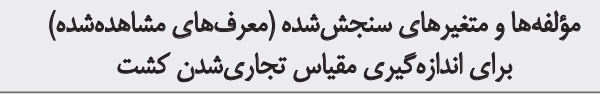 \\
\hline & & & - /VAa & 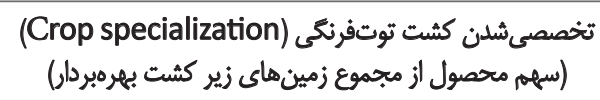 \\
\hline .1. &.$/ \pi$ & V/A & . /Ar. & 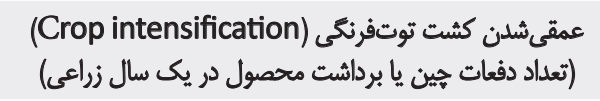 \\
\hline .1. & rות & NIE & $\cdot / 8+1$ & عملكرد محصول در واحد سطع (تُن بر هكتار) (Crop yield) \\
\hline+1. &.$/ 10$ & V/rT &.$/ 810$ & 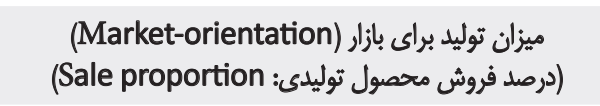 \\
\hline$+\%$ &.$M 1$ & $V / q F$ & ./D9T & 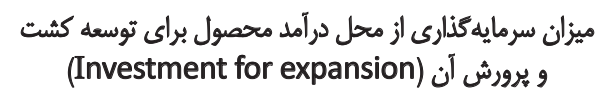 \\
\hline
\end{tabular}




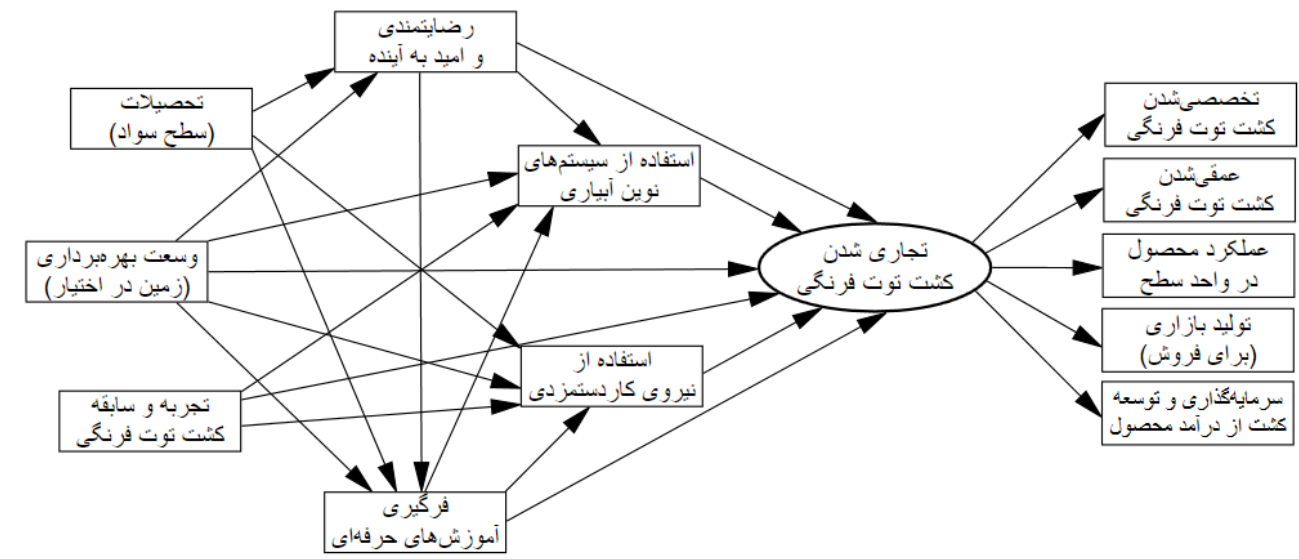

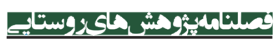

تصوير ץ. مدل تحليلى مفهومى مطالعه.

تجارىشدن كشت با استفاده از تحليل مسير تدوين مدل ثتاليلي مغهومى مطالكه

رسم نمودار و آرايش متغيرها در تحليل مسيي امرى اختيارى

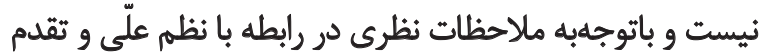

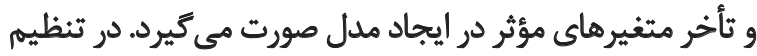

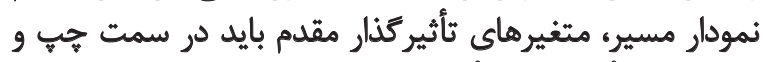

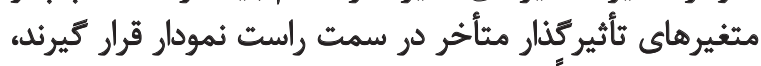

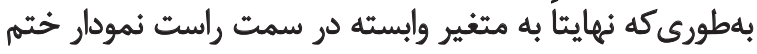

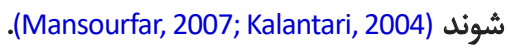

در صورتى كه محقق استدلال نظرى قوى براى آرايش متغيرها

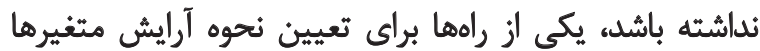

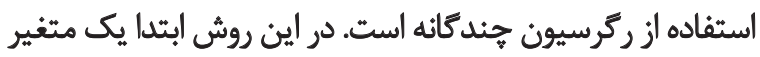

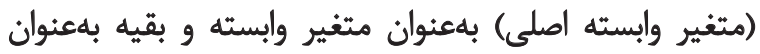

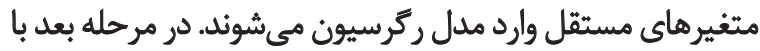

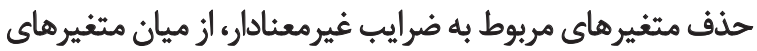

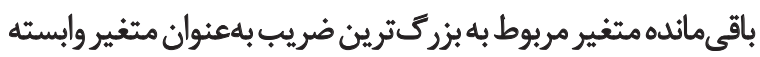

رابطه با مقياس، بيش از MI× بوده است. در ادامه به وزنها يا

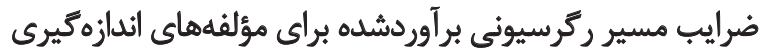

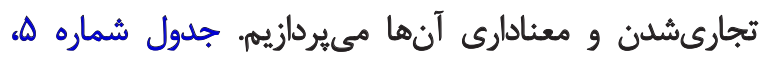

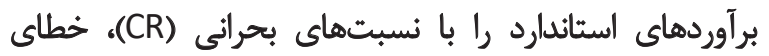

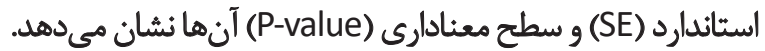

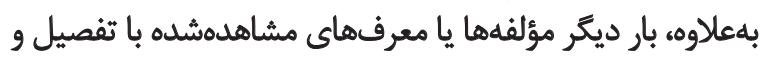

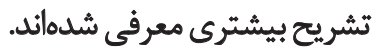
تمام مؤلفهها ضرايب ثأثير ركرسيوني مثبت با مقادير بيش از

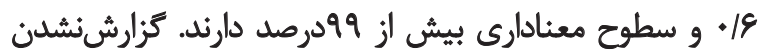

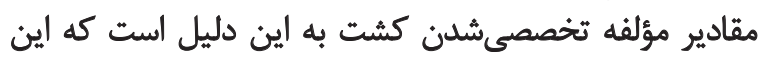

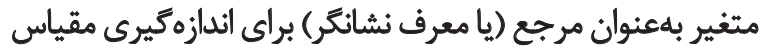

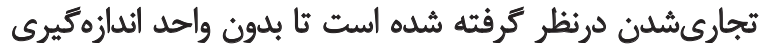

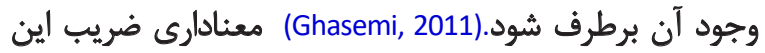

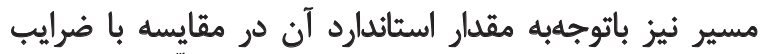

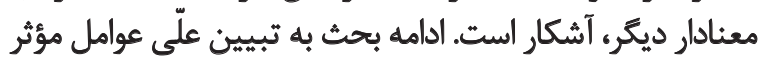
بر آن با استفاده مدل ساختارى تحليل مسير، اختصاص آدار دارد. مدلسازى ساختارى براى تبين علّى عوامل مؤثر بر

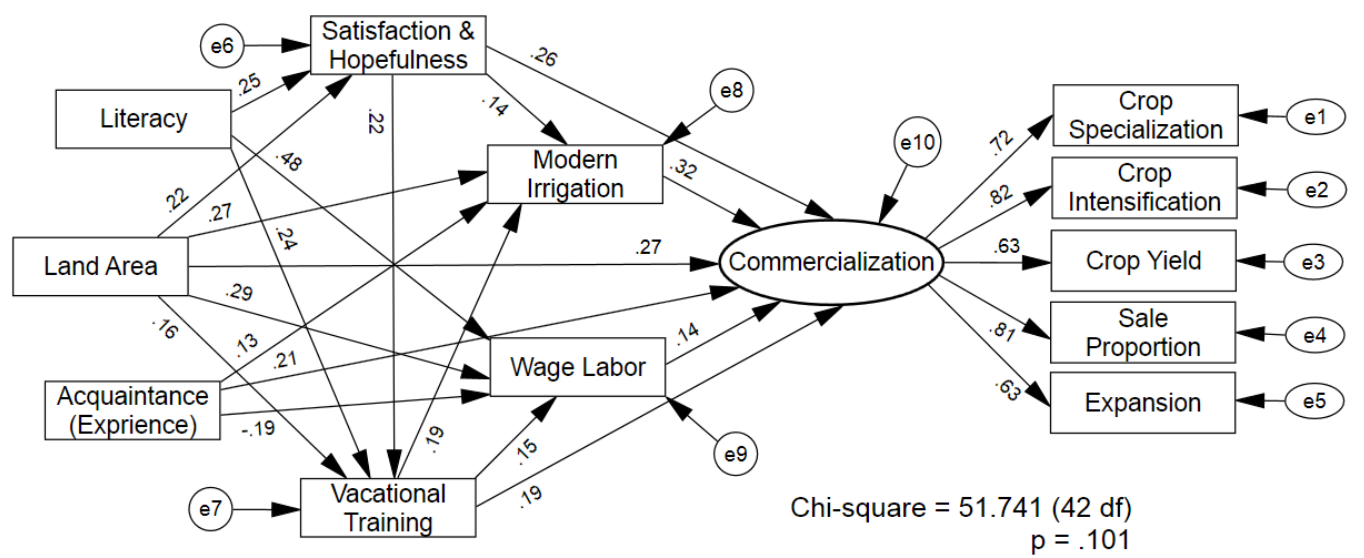

\section{مت}

تصوير P. برآوردهاي استاندارد حاصل از حل مدل ساختارى تحليل مسير براي تبيين عوامل مؤثر بر تجارىشدن كمت توتفرنكي در منطقه مطالعهشده. 
جدول و. برآوردهاى استائدارد براى مؤلفههاي مقياس تجارىشدن كشاورزى در مدل هاي اوليه و نهايى.

\begin{tabular}{|c|c|c|c|c|}
\hline \multicolumn{2}{|c|}{ مدل ساختارى نهايى } & \multicolumn{2}{|c|}{ مدل اندازهكيرى اوليه } & \multirow{2}{*}{ هؤلفههاى اندازهكيرى مقياس تجارىشلن } \\
\hline Sig. & ضريب مسير & Sig. & ضريب مسير & \\
\hline & .MT & & - NAD & تخصصى شُلن كشت \\
\hline$\%$ & - $|A| A$ & 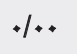 & - /AY & عمقى شلن كشت \\
\hline .10 & . Iapre & 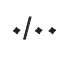 & $.18+1$ & عملكرد هحصول \\
\hline$\%$ &.$|A| r$ & 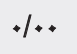 & .1810 & عرضه بازارى \\
\hline+1. & . IETO & +1. & - /DQT & توسعه كشت \\
\hline
\end{tabular}

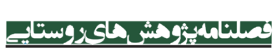

متغير ها هستند كه متغيرهاى متقدم آن را تبيين نكردهاند. از ميان متغيرهاى جدول شماره ثا، بهعنوان متغير هاى مستقل

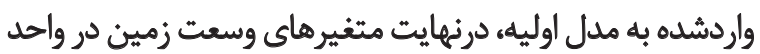

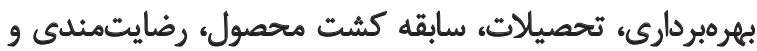
اميد به آينده، فراكيرى آموزشهاي تهاى حرفهاى، استفاده إز نيروى كار دستمزدى و استفاده از سيستمهاي نوين آبيارى، به به مدل فئل

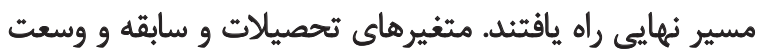

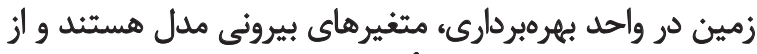

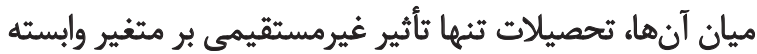

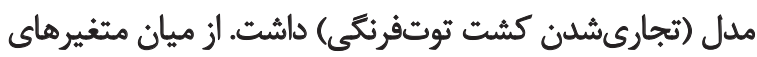

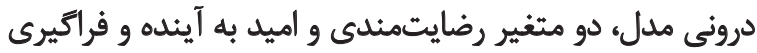

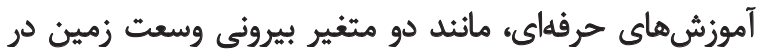

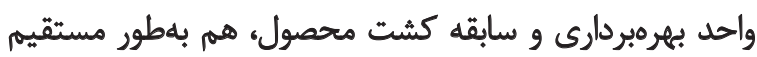

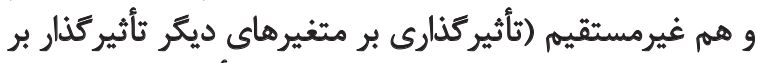

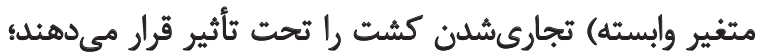

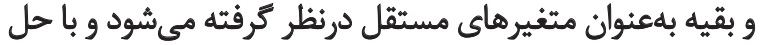

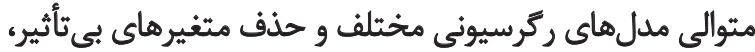

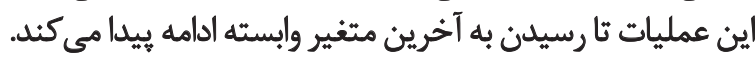
بدين ترتيب آخرين متغير يا متغيرها همان متغيرهاى بيرونى

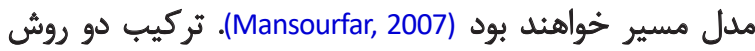
مذكور در مطالعه حاضر منجربه مدل تحليلىمفيهومى تصوير

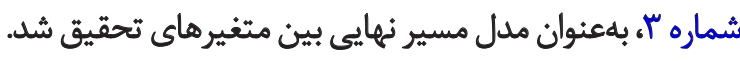
متغيرهاى هر مدل علّى، به دو گروه بيرونى و درونى تقسيهم

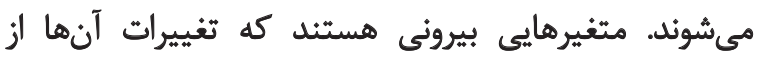

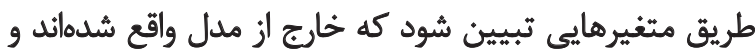

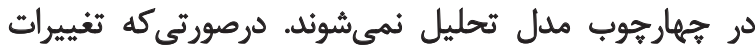

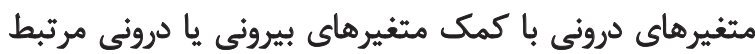

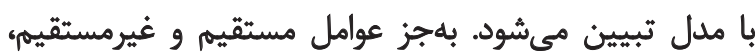

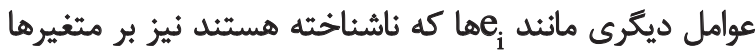

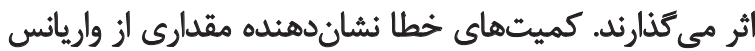

جدول V. اثرات مستقيم و غيرمستقيم و كل تأثيرات متغير هاى مستقل بر تجارى شدن كشت.

\begin{tabular}{|c|c|c|c|c|c|}
\hline \multirow{2}{*}{ 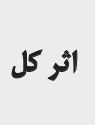 } & \multicolumn{2}{|c|}{ اثر غير مستئيم } & \multicolumn{2}{|c|}{ اثر رئرسيونى مستقيم } & \multirow{2}{*}{ عوامل تأثير كذار بر تجارىشدن كشت توتفرنتى } \\
\hline & مسير هاى اثر كذارى & مجموع ضرايب & Sig. & ضريب مسير & \\
\hline AMIA & - & - & $+\%$ & $+/ M M$ & استفاده از سيستمهاى نوين آييارى \\
\hline MFT & - & • & $\%$ & . MFt & استفاده از نيروى كار مزدى \\
\hline MV & 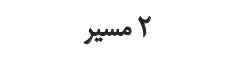 &.$/ \cdot A r$ & .1. &.$/ M$ & فراكيرى آموزش هاي حرقهاى \\
\hline.$/ R V$ & 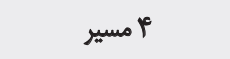 &.$/ 1 \cdot 0$ & .1. &.$/$ Tro & رضايتمندى و اميل به آيثله \\
\hline.$/ 01 Y$ & 1. (مسير & $. / T A \mid$ & .1. & . Tes & وسعت زمين در واحل بهرهبردارى \\
\hline . & 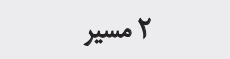 & $.1 \cdot 10$ & .1. & $\cdot / r+1$ & سابقه (تجربه) \\
\hline . MYE & 9 9سير & . MTE & & - & تحصيلات \\
\hline
\end{tabular}


تائهمترين بخش از خروجى هاي تحليل، مربوط به نحوه و ميزان

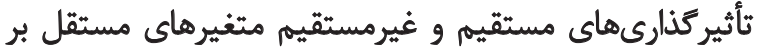

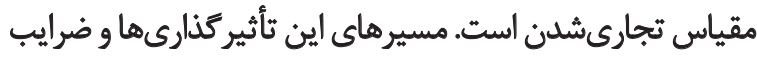

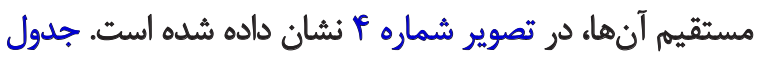

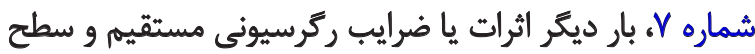

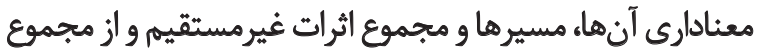

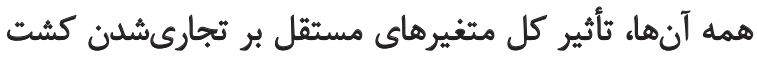
توتفرنكى در منطقه را نشان مي دهد.

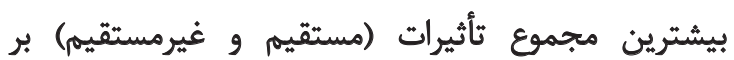

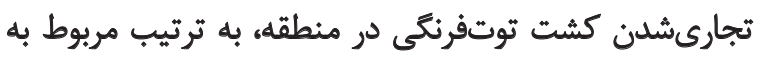

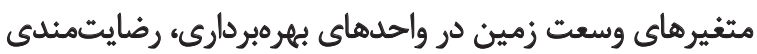

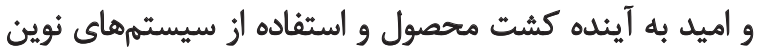

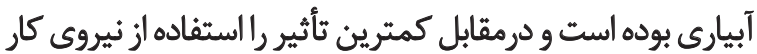
مزدى و سابقه كشت محصول و تحصيلات داشتهانداند

نزديك به نيمى از تأثير متغير زمين با ضريب اثركذارى كل

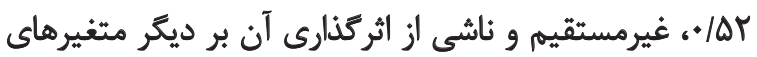

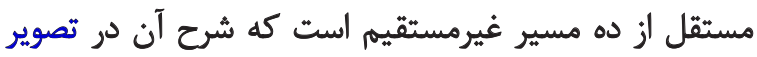

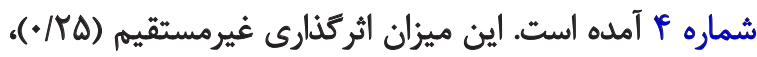

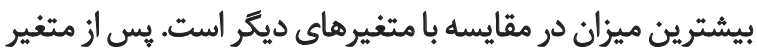

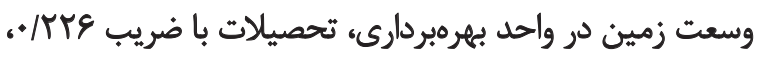

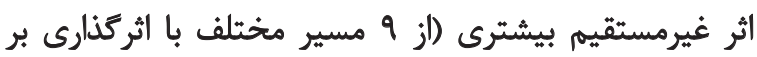

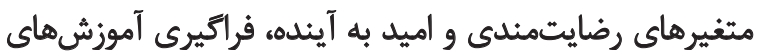

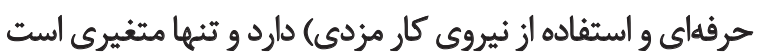

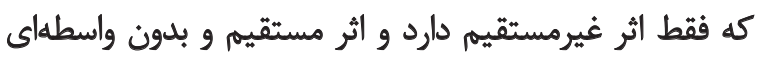

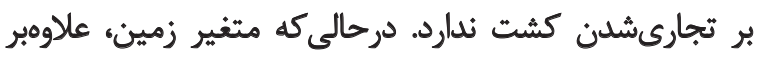

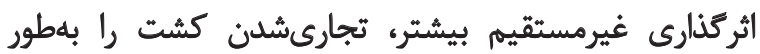
مستقيم نيز تحت ثأثير قرار مي دهدي

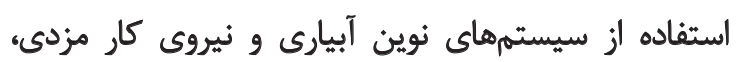

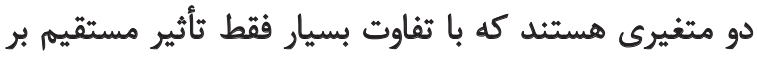

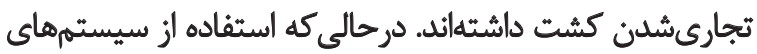

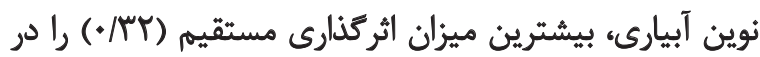

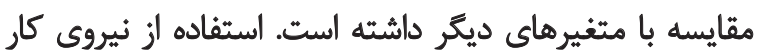

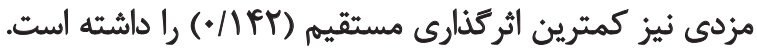

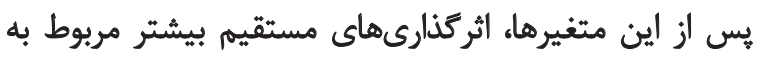

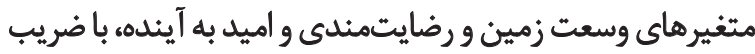

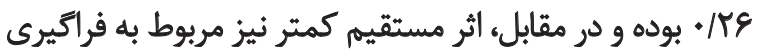

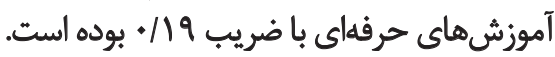

اثركذارى منفى سابقه فعاليت بر ميزان استفاده از نيروى برى بادي

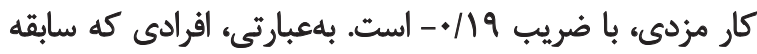

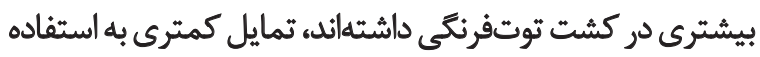

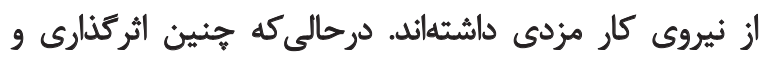

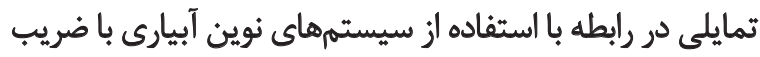

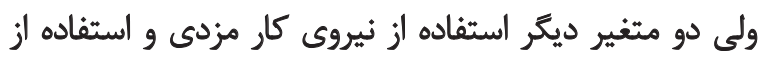

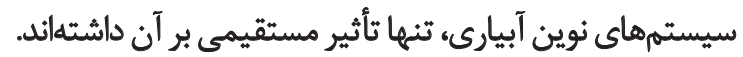

مسيريابى علّى و برآورد ضرايب مسير در مدل ساختارى تحليل اجراى مدل مسير شناسايي و تدوينشده و حل آن دآن در

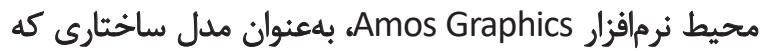

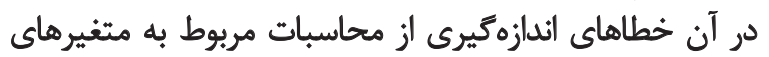

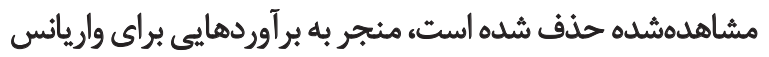

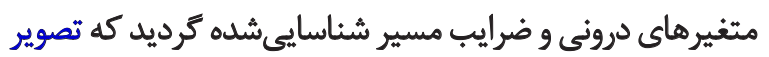
شماره Fا، برآور دهاى استاندارد ضرايب مسير بائ با مقدار كائ اسكوئر

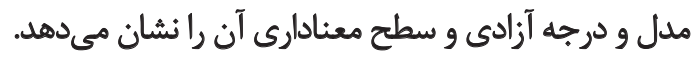

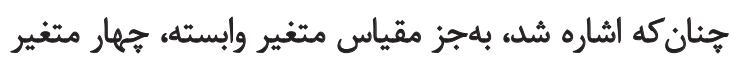

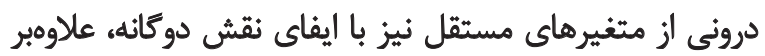

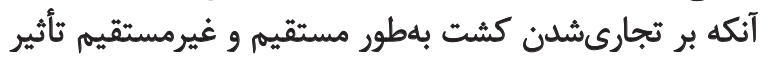

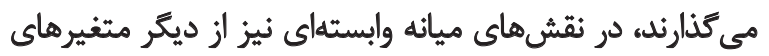

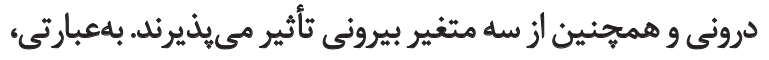

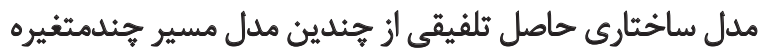

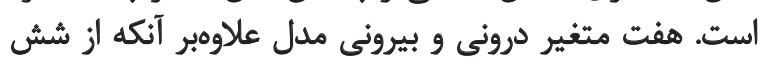

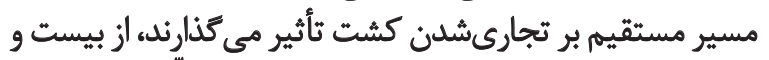

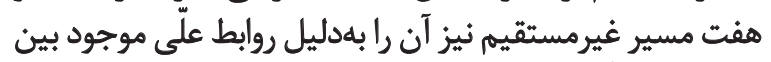
خود، تحت تأثير قرار مي دهند.

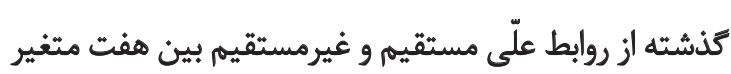

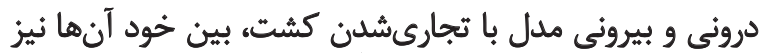

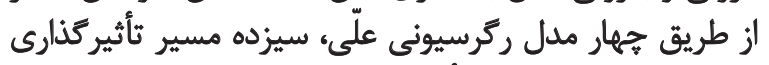

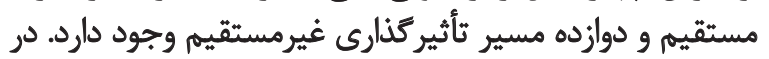

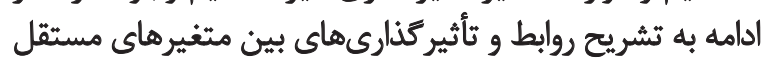

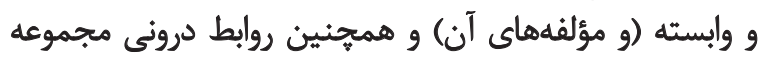
متغيرهاي مستقل با يكديكر خواهيم يرداخت وانئ.

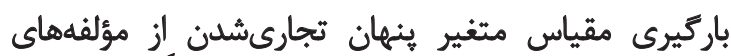

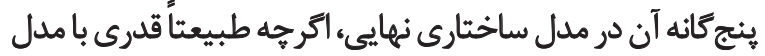

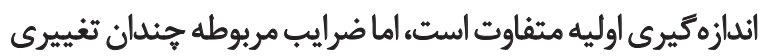

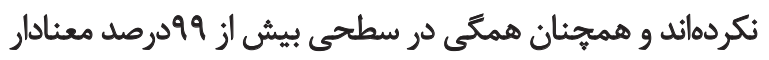

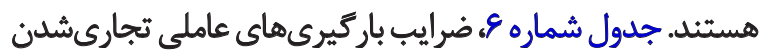

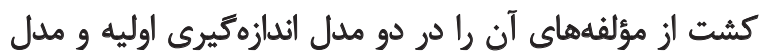
ساختارى نهايي نشان مي دهون ان رادي

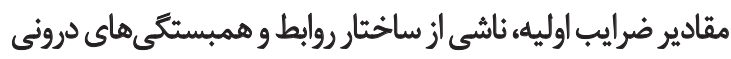

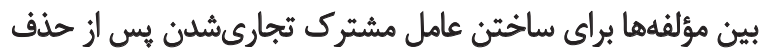

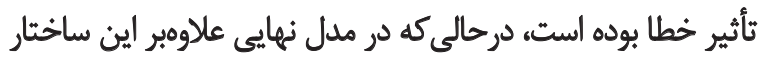

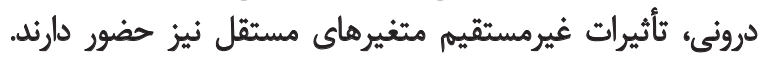

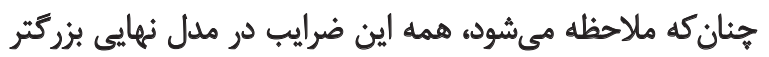

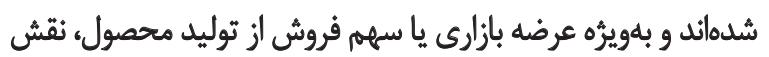

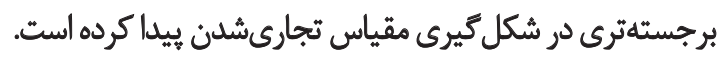


جدول A. اثر غيرمستقيم متغيرهاي مستقل بر مؤلفههاى مقياس وابسته تجارىشدن كشت.

\begin{tabular}{|c|c|c|c|c|c|}
\hline \multicolumn{5}{|c|}{ مؤلفهاي مشاهدهُشده مقياس وابسته و ونهان تجارىشدن كثت } & \multirow{2}{*}{ عوامل تأثير كئذار (مثغير هاي مستثل مشاهدهشده) } \\
\hline توسعه كشت & عرضه بازارى & عملكرد محصول & عمقى شـن كشت & تخصصى شُشن كشت & \\
\hline. $\mid r \Delta \Delta$ &.$/ 50$ &.$/ T \Delta$ & - /PAT &.$/ 499$ & وسعتت زمين در واجلد بهرهبردارى \\
\hline.$/ M T V$ & $\cdot \pi n \cdot r$ &.$/ M V$ & $\cdot \pi \cdot \varphi$ &.$/ T V$ & رضايتهندى و اميد به آينده \\
\hline.$/ T \cdot r$ &.$/$ TAQ & $\cdot M \cdot r$ &.$/ R 8$ &.$/ \pi$ & استُفاده از سيستمهاى نوين آييارى \\
\hline.$|1 \mathrm{~A}|$ & . MMr & $.|| A \mid$ & 每 & $\cdot \pi \cdot 8$ & فراكيرى أموزش هاى حرفهاى \\
\hline.$/ 179$ &. &.$/ 199$ &.$/ M T^{\prime}$ & $\cdot t r+\varphi$ & تحصيلات \\
\hline.$/ 109$ & $\cdot M+r$ &.$/ 109$ & $\cdot \pi+\Delta$ &.$|11|$ & استفاده از نيروى كار مزدي \\
\hline.$/ 17 q$ &.$/ 1 F \Delta$ &.$/ 1 K A$ &.$/ 1 \notin 8$ & -life & سابقه كشت و يرورش محصول \\
\hline
\end{tabular}

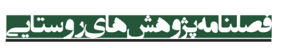

تأثيرى كه شرح آن در جدول شماره 9 آمده است، با باركيرى از ازئ

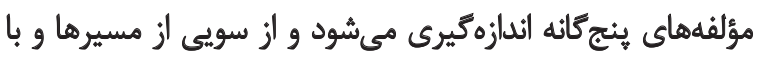

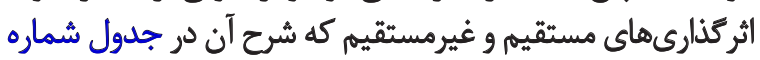

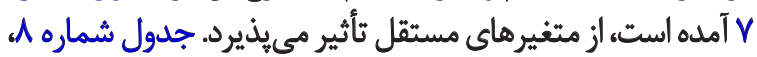

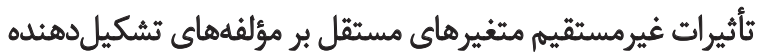

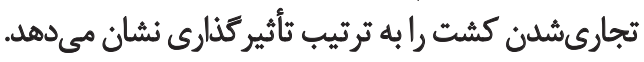

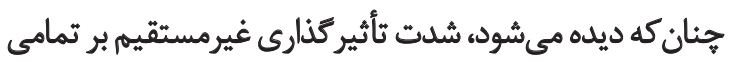

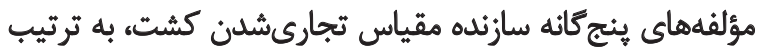

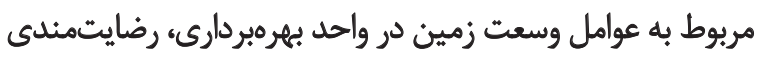

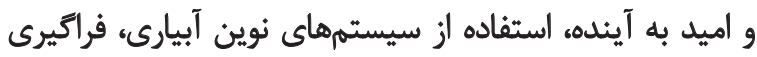

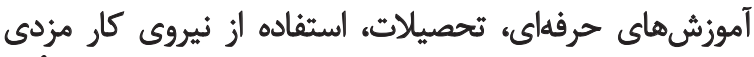

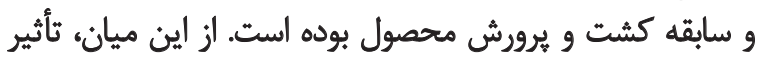

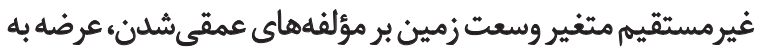
بازار و تخصصى شدن كشت، قابل توجهتر از بقيه مؤلفهائها بودهد است. تحليل مسير، روشى تحليلى براى كشف و بيان اثركذارىهاى

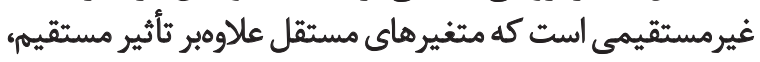

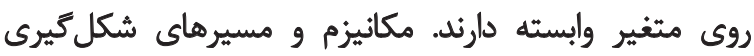

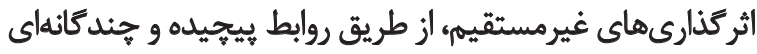

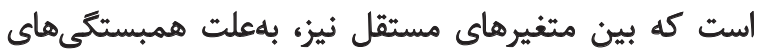

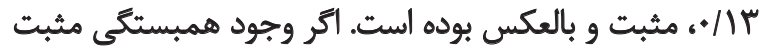

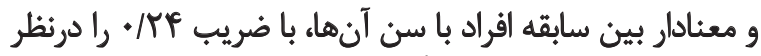

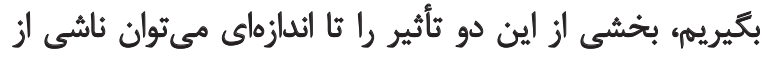

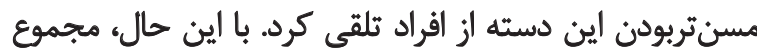

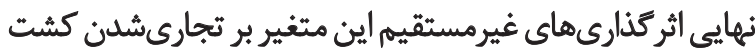

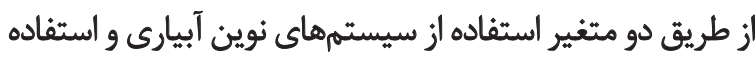

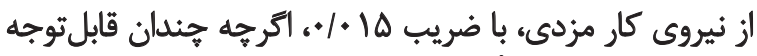

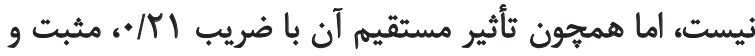
تقويت كنيله بوده است همون تأير مات

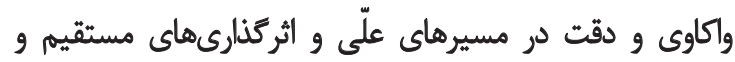

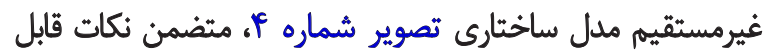

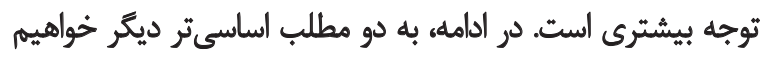

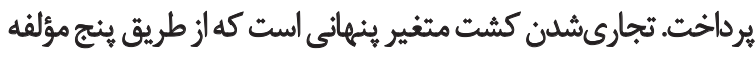

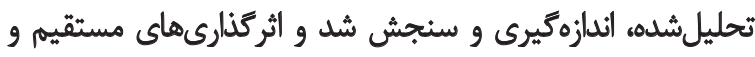

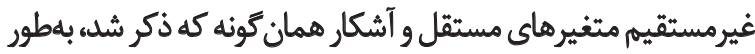

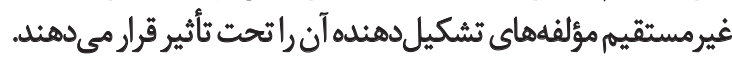

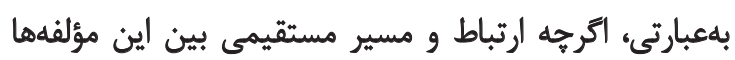

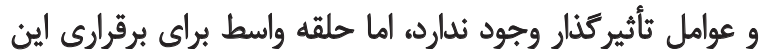

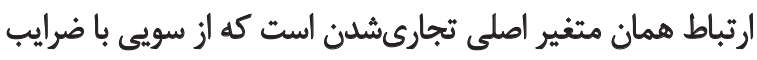

جدول ج. شاخصهاي برازش مدل علتىساختّارى تحليل.

\begin{tabular}{|c|c|c|c|c|c|c|c|c|c|}
\hline \multicolumn{9}{|c|}{ شاخصهاى برازش } & \multirow{2}{*}{ مدل على ساخثتارى تجارى شُدن كشاورزى } \\
\hline RMSEA & PRATIO & CFI & NFI & GFI & RMR & Sig. & df & CMIN & \\
\hline $.1+r$ & .19. &.$/ 41$ &.$/ 9 f$ & .198 & $\cdot / \Delta F^{\circ}$ & M. & Pr & $\Delta 1 / M^{e}$ & مقادير تجربي مدل \\
\hline$<* 1 \cdot \Delta$ & $\cdot-1$ & $>.19$ & $>. / 9$ & $>.19$ & $\approx$ & $>.1 .0$ & - & - & مقادير معيار ييشتنهادى" \\
\hline
\end{tabular}




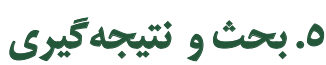

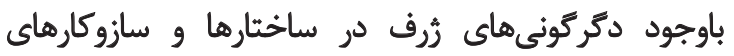

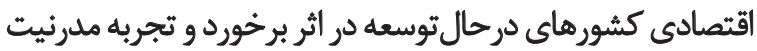

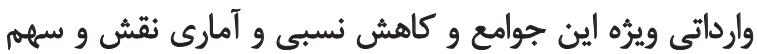

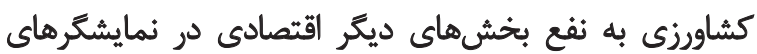

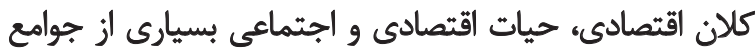

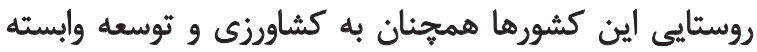

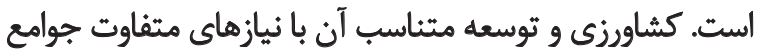

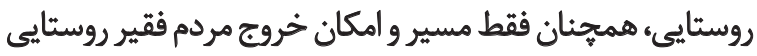

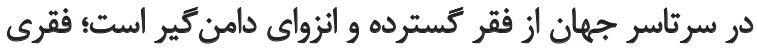

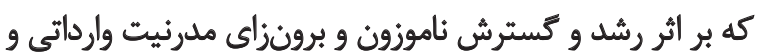

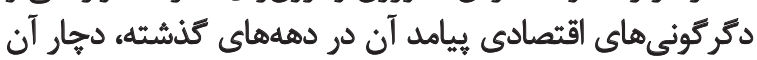

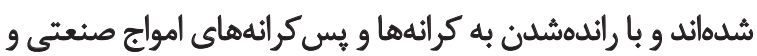
اطلاعاتى دنياى مدرن روزكار سيرى مي كنيند.

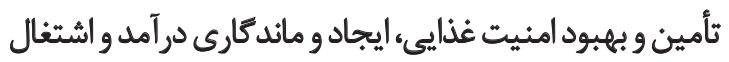

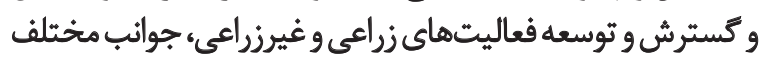

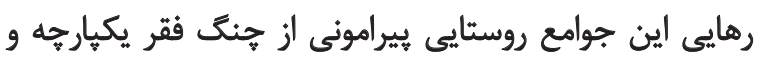

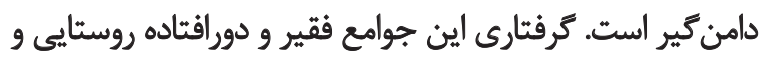

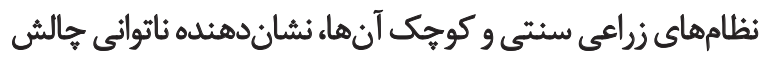

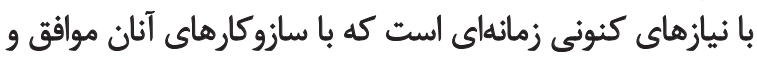

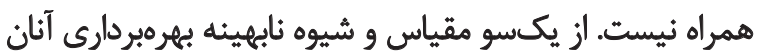

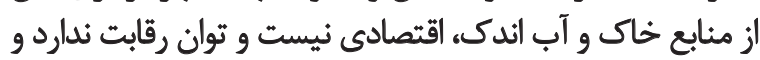

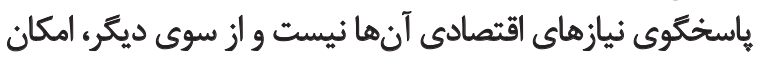

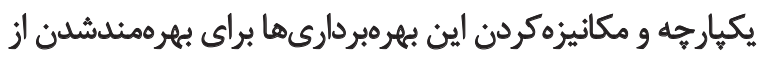

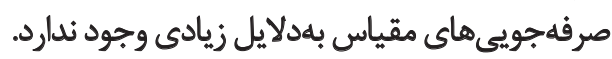

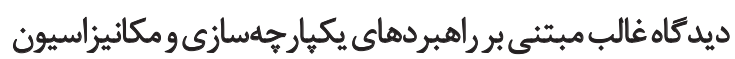

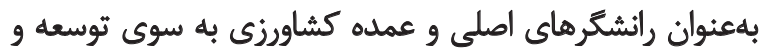

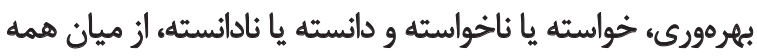

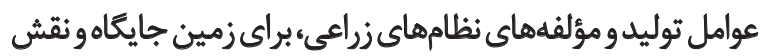

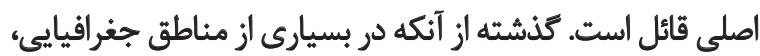

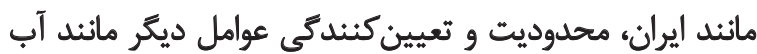

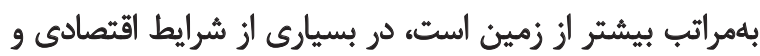

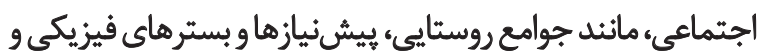

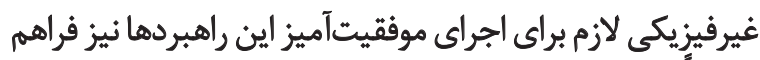

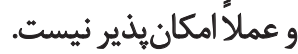

تجارىسازى بهرهبردارىهاى خُرد روستايى، با ثأكيد بر برائ

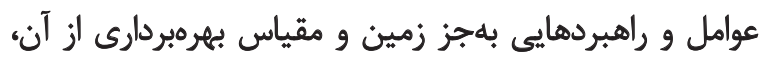

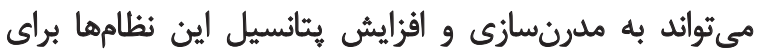

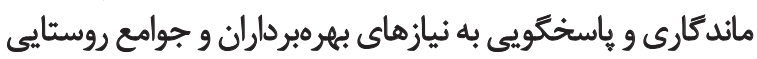

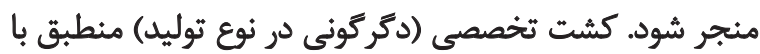

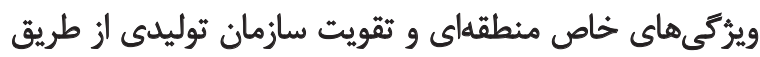
جريانهاى ورودى (نهادهاي مختى وختلف) و خروجى (محصول)،
ميان آنها وجود دارد. بنابراين، با شناسايي ترثيب تقدم و تأخر

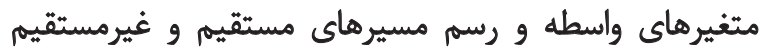

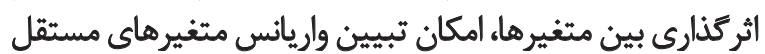
درونى مدل از طريق بقيه متغيرهاى مستقل نيز فئن فراهم مى مشود. مثتيرهاى درونى، متغير هايي هستند كه با ايفاى نقشى دوكانيه

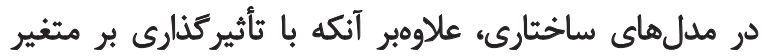

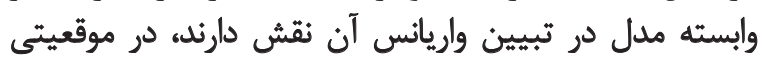

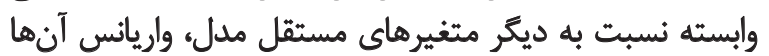

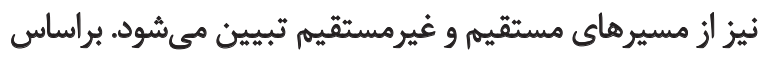

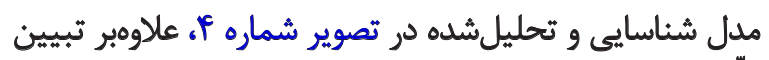

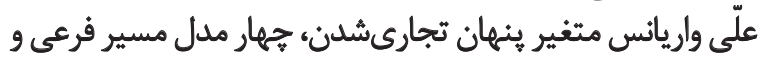

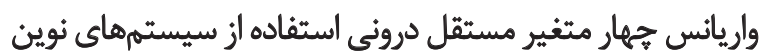

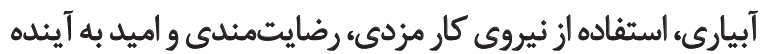

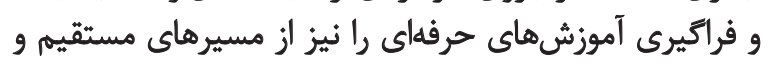
غير مستقيم تبيين مي كنيند. بدون ارائه نتايج تفصيلى اين مدل ها، به اختصار اشاره مي كنيم

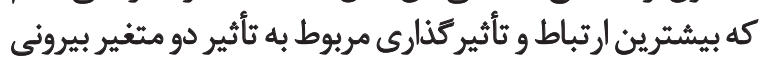

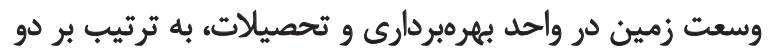

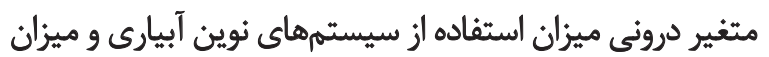

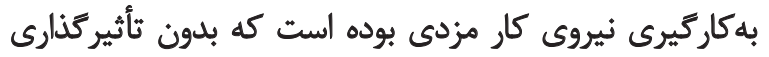

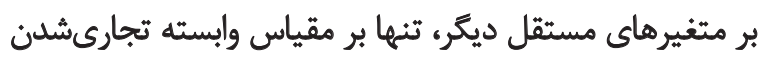
كشت ثأثير مستقيم دارند.

\section{اعتبار مدل علّى ساختارى تحليل و برآوردهاى حاصل از آن}

مدلسازىهاى ساختارى درواقع تثلاش براي تبيدين

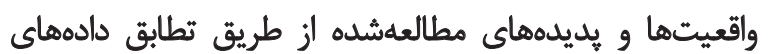

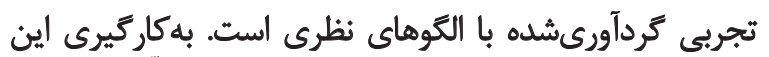

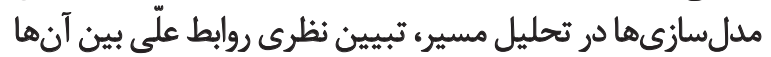

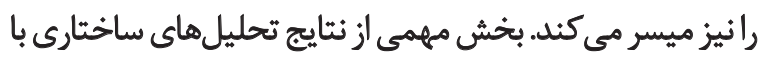

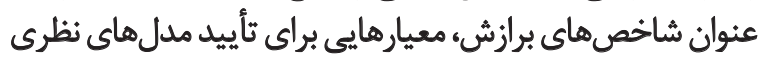

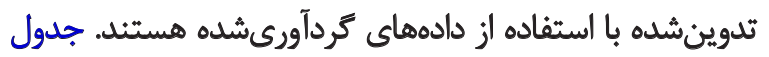

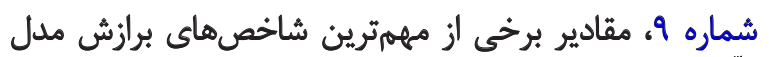

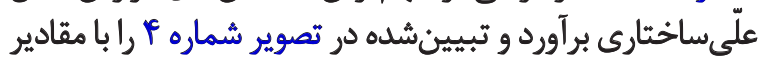
معيار آنها براى تصميم خيرى نشان مى دهد

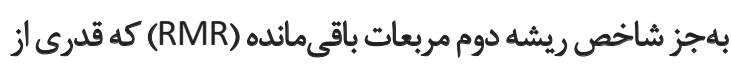

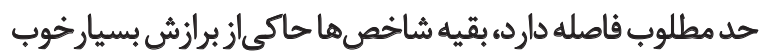

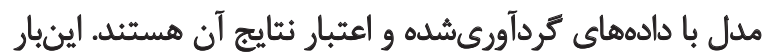

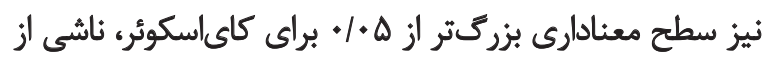

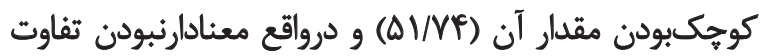

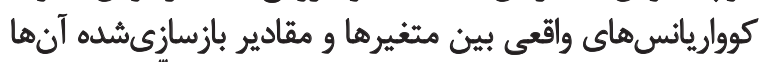

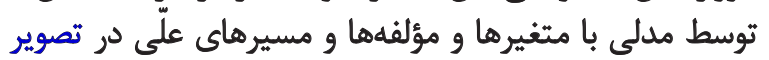

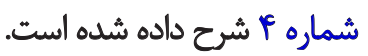




\section{References}

Abdar, M. (2009) [Agricultural transition from traditional to modern systems in Boyerahmad County (Persian)]. Isfahan: University of Isfahan Publication.

Abdollahi, M. (1999). [Farming systems: A comparative study and evulution of farming systems in Iran (Persian)]. Tehran: Ministry of Jihad-e Keshavarzi Publication.

Ashraf, A. (1983). [Peasants, land and revolution (Persian)]. In Agah Book Collections, Agrarian and Peasantry Problems (pp. 6-49). Tehran: Agah Publication.

Ansari, H. (1997). [The role of cooperatives in agricultural transition from subsistence to commercial production (Persian)]. Agricultural Economics and Development, 13, 330-45.

Azimi, H. (1983). [Distribution of land and income at the verge of agrarian reforms (Persian)]. In Agah Book Collections, Agrarian and Peasantry Problems (pp. 75-95). Tehran: Agah Publication.

Darbandi, A. (2000). [Transition of traditional agriculture to modern one in rural areas of Aligudarz County (Persian)]. Isfahan: University of Isfahan Publication.

Ghahreman, B. (1983). [Two notes on commercial agriculture in Iran (Persian)]. In Agah Book Collections, Agrarian and Peasantry Problems (pp. 135-55). Tehran: Agah Publication.

Ghasemi, V. (2011). [Structural equation modeling in social researches using Amos Graphics (Persian)]. Tehran: Jamee Shenasan Publication.

Houman, H. (2006). [Structural equation modeling with LISREL application (Persian)]. Tehran: Samt Publication.

Jihad-e Keshavarzi Organization of Kurdestan Province (2012). [Reports and statistics of Plan and Programming Office (Persian)]. Retrieved from http:/ / kurdistan.agri-jahad.ir.

Kalantari, Kh. (2004). [Data processing and analysis in socio-economical researches (Persian)]. Tehran: Sharif Publication.

Lai, J. Y., \& Lin, C. T. (2008). What factors drive corporate customer satisfaction with e-banking services? Paper presented at the $12^{\text {th }}$ Pacific Asia Conference on Information Systems, Suzhou, China, 3-7 July 2008 .

Mansourfar, K. (2007). [Advanced statistical methods using applied softwares (Persian)]. Tehran: University of Tehran Publication.

Moridi, S. (1997). [The necessity of commercialization in small farming holders (Persian)]. Agricultural Economics and Development, 13, 298-329.

Najafi, Gh. (1997). Management in commercial agriculture (Persian)]. Agricultural Economics and Development, 16, 59-88.

Nepal, R., \& Thapa, G. P. (2009). Determinants of agricultural commercialization and mechanization in the hinterland of a city in Nepal. Applied Geography, 29(3), 377-89. doi: 10.1016/j.apgeog.2008.12.002

Nowshirvani, V. (1983). [The beginning of commercialization in Iran's agriculture (Persian)]. In Agah Book Collections, Agrarian and Peasantry Problems (pp. 192-237). Tehran: Agah Publication.

Poole, N. D., Chitundu, M., \& Msoni, R. (2013). Commercialization: A meta-approach for agricultural development among smallholder farmers in Africa? Food Policy, 41, 155-65. doi: 10.1016/j. foodpol.2013.05.010

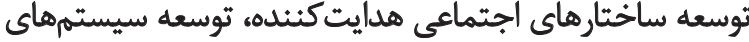

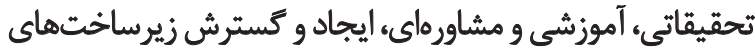
توسعهلى (جاده مناسب و دردسترس براى همه فصول ل، برق، مخابرات، شبكهاى آبيارى) بهويرّه سيستمهاى حمل بونقل، نكهارى و به بازاروسائلن محمول و ثوسعه صنايع ثبديلى

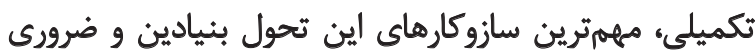

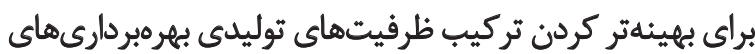
يراكنده وخُرد بهشمار مي آيند.

در اين راه، كشاورزان خُرد بلويثه در جوامع و كشورهاي

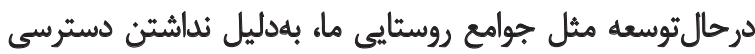

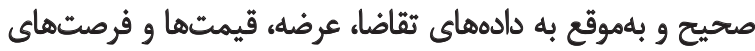

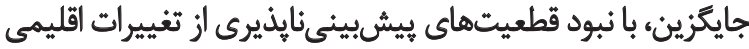

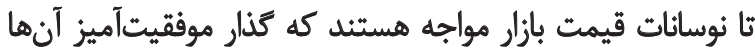

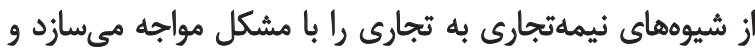

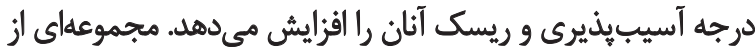

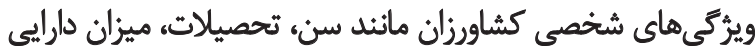

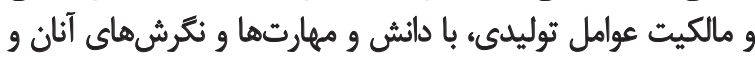

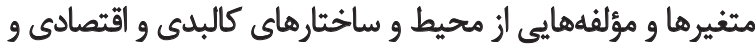

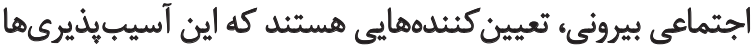

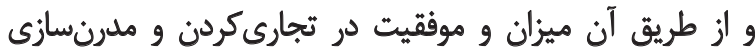
بهرببردارى هاى كوجك را تحت تأثير قرار مىدهند.

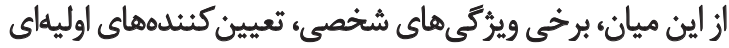

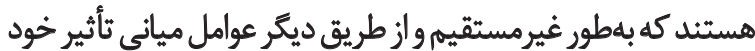

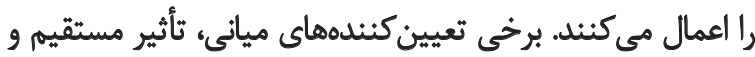

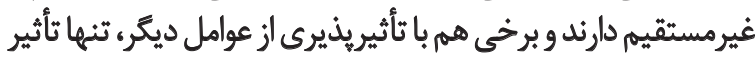

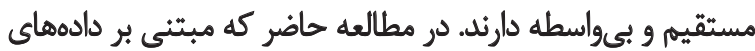

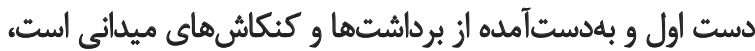

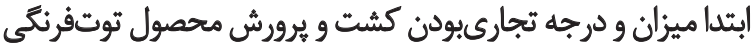

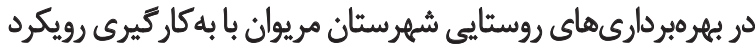

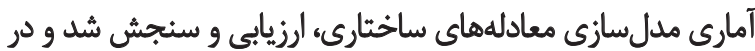

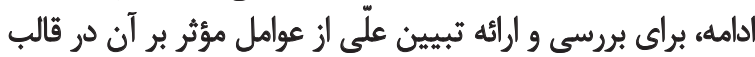

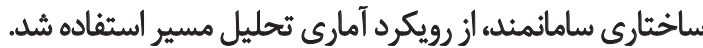

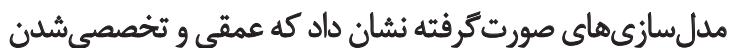

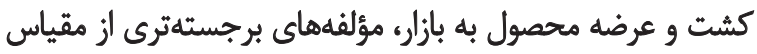

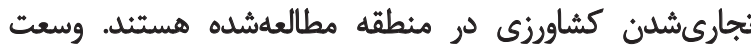

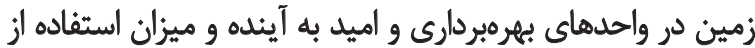

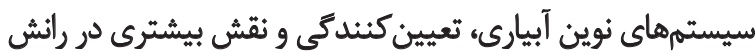

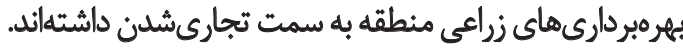

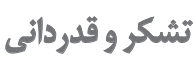
اين يُروهش حامى مالى نداشته است.

7. An all weather road 
Riwthong, S., Schreinemachers, P., Grovermann, C., \& Berger, T. (2015). Land use intensification, commercialization and changes in pest management of smallholder upland agriculture in Thailand. Environmental Science \& Policy, 45, 11-19. doi: 10.1016/j.envsci.2014.09.003

Taherkhani, M., \& Rahmani, D. (2006). [Specialization of cultivation pattern and its role in rural development (Case study: Strawberry cultivation in Javroud region of Marivan County) (Persian)]. Journal of Spatial Planning, 10(1), 81-102. 